
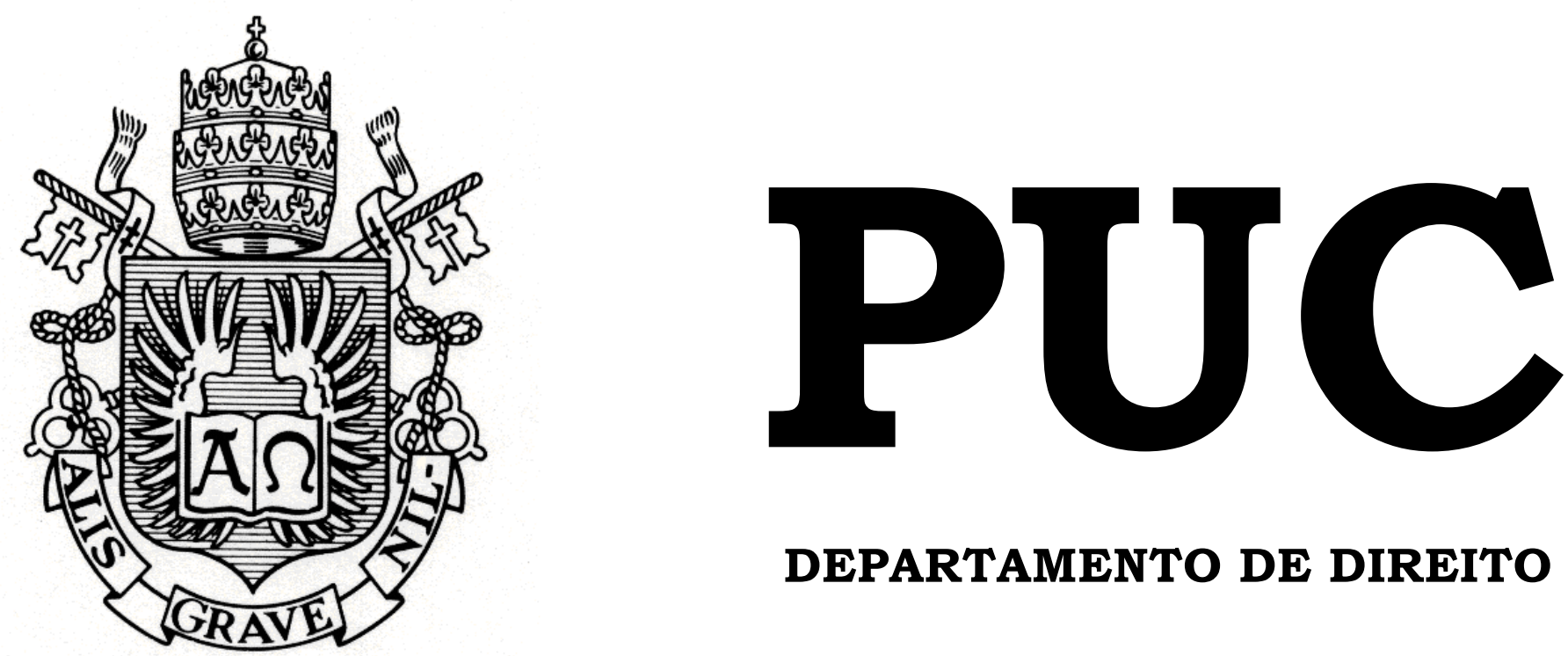

DEPARTAMENTO DE DIREITO

\title{
A AUTORREGULAMENTAÇÃO PUBLICITÁRIA NO BRASIL
}

\author{
por \\ CANDIDO EDUARDO MENDES DE ALMEIDA
}

ORIENTADOR: Ricardo Brajterman

2013.2

PONTIFÍCIA UNIVERSIDADE CATÓLICA DO RIO DE JANEIRO

RUA MARQUÊS DE SÃO VICENTE, 225 - CEP 22453-900

RIO DE JANEIRO - BRASIL 


\title{
A AUTORREGULAMENTAÇÃO PUBLICITÁRIA NO BRASIL
}

\author{
por
}

\section{CANDIDO EDUARDO MENDES DE ALMEIDA}

Monografia apresentada ao Departamento de Direito da Pontificia Universidade Católica do Rio de Janeiro (PUC-Rio) para a obtenção do Título de Bacharel em Direito.

Orientador: Ricardo

Brajterman 
Para a minha mãe, Angela, $e$ meu avô, Candido. 


\section{Agradecimentos.}

Ao meu orientador, Ricardo Brajterman, e ao Helder Galvão, pelas instruções e disponibilidade, fundamentais para a elaboração deste trabalho.

À minha mãe, Angela, por tudo que fez e sacrificou por mim, e por ter feito questão de abrir a minha cabeça para o mundo desde pequeno.

Aos meus avôs e avó. Candido e Haroldo, por terem me transmitido e incentivado o amor pela política e pela história. E Tininha, pelo carinho incondicional.

À Maria, pelo amor e companheirismo, mesmo quando a distância geográfica não ajuda.

Ao grande publicitário Carlos Di Celio, o Russo, por ter acreditado em mim e dado a oportunidade profissional que mudou a minha vida.

E, finalmente, aos meus amigos-irmãos Ricardo, João Marcelo, Gustavo e, em especial, ao Pedro Pio, por todos os "galhos quebrados" nestes cinco anos de PUC. 
ALMEIDA, Candido Eduardo Mendes de. A Autorregulamentação Publicitária no Brasil. Rio de Janeiro: 2013: 72 p. Monografia de final de curso. Departamento de Direito da Pontifícia Universidade Católica do Rio de Janeiro - PUC-Rio. 


\section{Resumo}

Este trabalho tem por objetivo abordar o tema da autorregulamentação publicitária no Brasil. Em um primeiro momento, aborda-se o conceito da publicidade e o fenômeno da autorregulação. Em seguida, é apresentado o modelo misto de regulamentação da publicidade, vigente no país e, segundo o qual, a regulação da propaganda é exercida tanto pelo Estado, quanto pelo próprio mercado publicitário. A partir de então, a autorregulamentação é explorada a fundo, sempre sob a ótica do direito. Após a análise do órgão responsável pela autorregulação, o CONAR, são apresentadas algumas de suas decisões, tendo como linha condutora os princípios do Código Brasileiro de Autorregulamentação Publicitária.

A concorrência desleal - tipificada na Lei de Propriedade Industrial - e a sua intrínseca relação com a publicidade, é abordada em seguida, assim como a proteção autoral das obras publicitárias. Por fim, também são apresentadas as experiências de autorregulamentação da publicidade no Reino Unido e nos Estados Unidos.

\section{Palavras-chave.}

Autorregulamentação - autorregulação - publicidade - propaganda CONAR - Código Brasileiro de Autorregulamentação Publicitária princípios gerais do Código Brasileiro de Autorregulamentação Publicitária - concorrência desleal. 


\section{Sumário}

I. Introdução

II. Publicidade, autorregulação, e regulamentação mista........... 10

I.1 O que é a publicidade?................................................... 10

I.2 O fenômeno da autorregulação........................................ 11

I.3 O modelo misto de regulamentação da

publicidade

III. O Conselho Nacional de Autorregulamentação Publicitária -

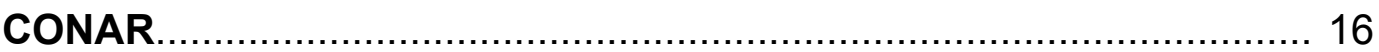

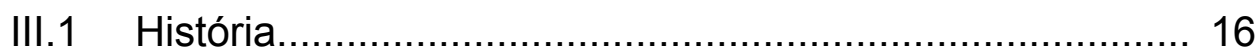

III.2 Considerações preliminares............................................. 17

III.3 Composição e funcionamento........................................... 19

III.3.1. Conselho de Ética.................................................. 21

III.3.1. Processos éticos no CONAR ....................... 23

III.3.2. Conselho Superior............................................... 24

IV. O Código Brasileiro de Autorregulamentação Publicitária e

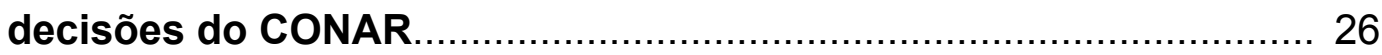

IV.1 O Código Brasileiro de Autorregulamentação Publicitária

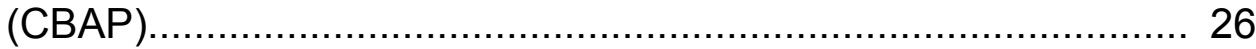

IV.2 Os princípios gerais do CBAP e casos julgados pelo

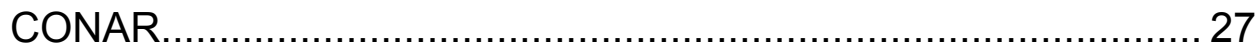

IV.2.1 Respeitabilidade............................................ 27

IV.2.2 Honestidade e Apresentação Verdadeira............... 31

IV.2.3 Medo, Superstição, Violência................................... 35

IV.2.4 Identificação Publicitária........................................... 37

IV.2.5 Propaganda Comparativa...................................... 39

IV.2.6 Segurança e Acidentes......................................... 41

IV.2.7 Poluição e Ecologia.................................................. 43

IV.2.8 Crianças e Jovens................................................ 45 
V. Publicidade, concorrência desleal e direitos autorais........... 53

V.1 Publicidade e a concorrência desleal............................... 53

V.2 A proteção autoral das obras publicitárias......................... 57

VI. A autorregulação publicitária em outros países..................... 61

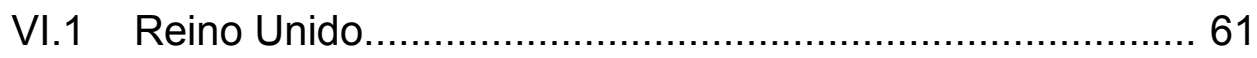

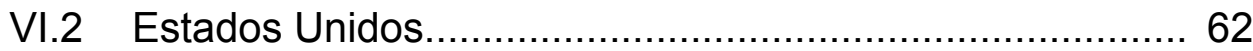

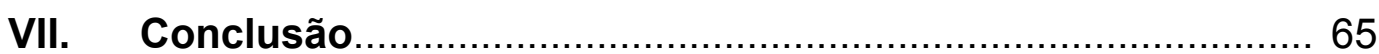

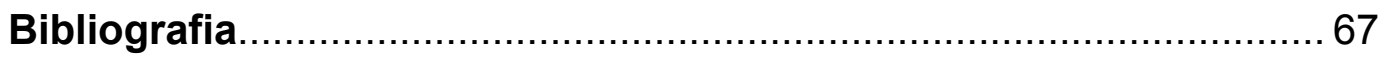




\section{Introdução}

A publicidade é um mercado que movimenta bilhões de dólares mundo afora e outros tantos bilhões de reais no Brasil. Mais do que isso, é uma indústria que exerce uma influência potencial enorme sobre os consumidores e demais destinatários das suas mensagens. Por isso, é indispensável a existência de um sistema que, ao estabelecer mínimos padrões éticos, regule de maneira eficaz e eficiente as atividades realizadas pelo meio publicitário. Neste sentido, em um país que se notabiliza pela interferência muitas vezes excessiva do Estado nos mais variados setores da economia, a experiência brasileira de autorregulamentação na publicidade representa um modelo muito bem acabado de auto-organização e autocontrole do mercado.

O objetivo deste trabalho é abordar, através de uma ótica jurídica, o sistema de autorregulamentação publicitária no Brasil. Criado no final dos anos 1970, o CONAR é o órgão responsável pelo exercício da atividade autorreguladora no campo da publicidade nacional. Como será visto, através de uma estrutura célere, desburocratizada, e de fácil acesso pelo consumidor, centenas de casos são julgados todos os anos pelo Conselho de Ética do CONAR. Ainda que alguns doutrinadores consumeristas questionem a eficácia das decisões proferidas pelo órgão, não dotadas de coercibilidade, o índice de observância e cumprimento destas é de praticamente cem por cento.

Ademais, a função principal do CONAR não é apenas defender os direitos do consumidor frente à publicidade, mas garantir que os anunciantes respeitem os princípios éticos atinentes à publicidade e à concorrência leal. Ao adotar o modelo misto de regulamentação da publicidade, o Brasil conferiu ao Código de Defesa do Consumidor, ou seja, ao Estado lato sensu, a tutela dos direitos do consumidor perante a manifestação publicitária. 
Como será visto, no julgamento das representações que chegam ao CONAR, os conselheiros do órgão utilizam os princípios atinentes à publicidade, previstos no Código Brasileiro de Autorregulamentação Publicitária (CBAP), como principal fonte normativa. Dentre esses, é possível destacar os princípios da identificação publicitária, respeitabilidade, honestidade e apresentação verdadeira. É interessante notar que o CBAP, redigido em 1978, é anterior ao Código de Defesa do Consumidor e ao Estatuto da Criança e do Adolescente (ECA), ambos de 1990. Estes dois diplomas normativos, no que tange à publicidade, possuem princípios e artigos muito parecidos com aqueles do $\mathrm{CBAP}^{1}$.

Como também será visto, o sistema de autorregulamentação da publicidade é um importantíssimo mecanismo de defesa da concorrência leal. Assim como o CONAR existe para proteger o cidadão perante uma eventual propaganda que não atenda aos princípios éticos, também protege as empresas que atuam em um determinado mercado. Ao estipular os parâmetros éticos da atividade publicitária, o CBAP busca evitar de todas as formas que empresas anunciantes utilizem artifícios desleais para captar a clientela dos concorrentes. Outro tema relevante que diz respeito à publicidade é a proteção conferida pelo direito autoral às obras publicitárias. Anúncios em revistas, comerciais de televisão, são obras coletivas ou de coautoria? À quem cabe os direitos autorais sobre as mesmas? A questão é devidamente analisada no capítulo quinto deste trabalho.

O modelo britânico de autorregulamentação publicitária, talvez o mais bem sucedido no mundo, foi a maior inspiração para a implementação do sistema brasileiro. Junto com o modelo norte-americano, o modelo do Reino Unido também será objeto de análise deste trabalho, que se inicia aqui.

\footnotetext{
${ }^{1}$ É o caso, por exemplo, do art. 79 do ECA: Art. 79. As revistas e publicações destinadas ao público infanto-juvenil não poderão conter ilustrações, fotografias, legendas, crônicas ou anúncios de bebidas alcoólicas, tabaco, armas e munições, e deverão respeitar os valores éticos e sociais da pessoa e da família.
} 


\section{Publicidade, autorregulação e regulamentação mista}

\section{II.1. O que é a publicidade?}

A publicidade está por toda a parte. Diluída em pequenos banners de internet ou amplificada por outdoors e comerciais no intervalo da novela das oito da Rede Globo, a mensagem publicitária é incansável, e muitas vezes agressiva, na busca pela atenção do consumidor. No contexto das sociedades de consumo de massa, no qual a maioria absoluta da população mundial está inserida, é muito difícil permanecer completamente alheio às manifestações da publicidade.

Antes de tudo, faz-se necessário esclarecer uma questão terminológica. Ainda que muitos autores façam uma distinção entre "publicidade" e "propaganda", ao longo deste trabalho os termos serão utilizados indistintamente, como sinônimos.

Mas o que é exatamente esta técnica tão utilizada por empresas e organizações em geral?

Para Rafael Sampaio, a propaganda é "a manipulação planejada da comunicação visando, pela persuasão, promover comportamentos em benefício do anunciante que a utiliza" ${ }^{2}$. No mesmo sentido, Armando Sant'anna define a publicidade como "uma técnica de comunicação de massa, paga com a finalidade precípua de fornecer informações, desenvolver atitudes e provocar ações benéficas para os anunciantes, geralmente para vender produtos ou serviços" ${ }^{\text {"3 }}$ Para o comitê de definições da American Association of Advertising Agencies (AAAA) "publicidade é toda e qualquer forma paga de apresentação impessoal e promoção tanto de ideias, como de bens ou serviços, por um patrocinador identificado" 4 .

\footnotetext{
${ }^{2}$ SAMPAIO, Rafael. Propaganda de A a Z. Rio de Janeiro: Elsevier, 2003, p. 26.

${ }^{3}$ SANT'ANNA, Armando. Propaganda: Teoria, Técnica e Prática, 3a ed. São Paulo, Pioneira, p. 76.

${ }^{4}$ BENJAMIN, Antônio Herman V.; MARQUES, Claudia Lima; Bessa, Leonardo Roscoe. Manual de Direito do Consumidor. 3. ed. rev., atual. e ampl. São Paulo: Editora Revista dos Tribunais,
} 
No dizer de Adalberto Pasqualotto, a publicidade é "toda comunicação de entidades públicas ou privadas, inclusive as não personalizadas, feita através de qualquer meio, destinada a influenciar o público em favor, direta ou indiretamente, de produtos ou serviços, com ou sem finalidade lucrativa" ${ }^{5}$. Paulo Vasconcelos Jacobina, por sua vez, enxerga a publicidade como a atividade empresarial "realizada com o objetivo de ofertar um bem ou serviço a consumo, através de um meio de comunicação capaz de atingir, ainda que potencialmente, um número indeterminado de pessoas, e veiculada às expensas do fornecedor"

Visto todas essas definições, fica mais clara a razão de ser da publicidade: persuadir e influenciar. Seja por meio de anúncios em revistas e jornais, comerciais na televisão, spots de rádio, filmes para a internet, entre outras peças, a função primordial da publicidade é chamar a atenção do consumidor para um produto ou serviço. Na medida em que a esfera de influência da publicidade pode ser gigantesca - vide os comerciais veiculados para milhões de telespectadores no intervalo de jogos de futebol, por exemplo - torna-se imprescindível a observância de padrões éticos na atividade publicitária. E isso só é possível através de certos mecanismos de controle. E, se este controle puder ser feito pelos próprios agentes do mercado, de maneira rápida e eficiente, sem a necessidade de ingerência do Estado, do Poder Judiciário, e de toda a máquina paquidérmica que os acompanha, melhor ainda.

\section{II.2. O fenômeno da autorregulação}

2010, p. 229.

${ }^{5}$ PASQUALOTO, Adalberto. Os efeitos Obrigacionais da Publicidade no Código de Defesa do Consumidor. São Paulo: RT, 1997, p. 25

${ }^{6}$ JACOBINA, Paulo Vasconcelos. A publicidade no direito do consumidor. Rio de Janeiro:

Forense, 2002, p 11. 
A autorregulação pode ser definida como o processo regulatório no qual a própria indústria, ao invés de um órgão governamental, define e aplica as regras e parâmetros de conduta que devem ser observados pelas empresas atuantes naquele mercado ${ }^{7}$. Ou seja, o poder regulamentar que em princípio cabe apenas ao Estado é conferido à uma entidade privada organizada pelos players do mercado. Ao redor do mundo, diversos setores da economia, dos mais variados, escolheram se autorregular. Nos Estados Unidos, a mineração, a pesca marinha e a indústria nuclear são alguns exemplos de indústrias que exercem a autorregulação ${ }^{8}$. No Brasil, além do mercado publicitário, é possível citar o sistema bancário (através da FEBRABAN) e o mercado de capitais (através da ANBIMA), como experiências bem sucedidas no âmbito autorregulatório.

São muitos os motivos que levam uma indústria a optar pela autorregulação. Via de regra, a opção pela estruturação de um sistema autorregulatório ocorre ou pela ausência de regulação por parte do Estado, ou pela ameaça de regulação governamental excessiva. Dentre os maiores benefícios da autorregulação, estão a velocidade e flexibilidade na edição de normas e procedimentos, custos menores e uma maior sensibilidade na avaliação das questões do mercado ${ }^{9}$, quando comparado à regulação exercida pelo Estado.

Também no que tange à autorregulação, é importante observar que "nenhuma norma de auto-regulação, por mais privada que seja - quanto à entidade que a elabora -, tem absoluto desprendimento das normas de ordem pública e de bons costumes"10.

\footnotetext{
${ }^{7}$ GUPTA, Anil K.; LAD, Lawrence J. Industry Self-Regulation: An Economic, Organizational, and Political Analysis. Boston: The Academy of Management Review 8 no. 3, 1983. p. 417. ${ }^{8}$ CASTRO, Daniel. Benefits and Limitations of Industry Self-Regulation for Online Behavioral Advertising. Disponível em $<\mathrm{http} / / / \mathrm{www}$.ntia.doc.gov/files/ntia/2011-self-regulation-onlinebehavioral-advertising.pdf $>$. Acesso em 18 out. 2013.

${ }^{9}$ GUNNINGHAM, Neil; REES, Joseph. Industry Self-Regulation: An Institutional Perspective. Disponível em $<\mathrm{http}: / /$ onlinelibrary.wiley.com/store/10.1111/1467-9930.t01-1-00033/asset/14679930.t01-1-00033.pdf? $v=1 \& t=h n 9 k n j i 8 \& s=a d 907 b 6621148 a 8$ fae 78b4a4a871615fc58b5714>. Acesso em 18 out. 2013.

${ }^{10}$ CARISTINA, José Eduardo Aguiar. Os modelos jurídicos na auto-regulação econômica. Prisma Jurídico, São Paulo, v.5, p. 121, 2006.
} 
No Brasil, a experiência com a autorregulação da publicidade é uma das mais bem sucedidas iniciativas do gênero. Nas palavras de Fábio Ulhoa Coelho, "a auto-regulação publicitária é, no Brasil, a mais interessante experiência de disciplina de atividade econômica por iniciativa dos próprios agentes nela envolvidos." ${ }^{11}$ Para Marco Antonio Marcondes Pereira, é "acima de tudo uma manifestação de controle democrático da própria sociedade, que, sem a ingerência do Estado, estabelece os rumos éticos da publicidade." 12

\section{II.3. O modelo misto de regulamentação da publicidade}

Antes de se proceder à análise da autorregulação publicitária em si, faz-se fundamental tecer algumas considerações acerca da regulamentação lato sensu da publicidade.

Até o final da década de 1980, como leciona Adalberto Pasqualotto, as normas que direta ou indiretamente se vinculavam à regulamentação estatal da publicidade eram casuísticas e assistemáticas ${ }^{13}$. Até então, o controle da publicidade no Brasil estava adstrito à autorregulamentação exercida pelo CONAR (Conselho Nacional de Autorregulamentação Publicitária). Era, portanto, um sistema de regulação exclusivamente privado - "aquele em que a publicidade submete-se ao crivo de organismos da sociedade, responsáveis pela atividade publicitária, com fundamento na livre-concorrência" $" 14$.

No entanto, com o advento do Código de Defesa do Consumidor, em 1990, como assinala Antonio Herman de Vasconcellos e Benjamin, “abre-

\footnotetext{
${ }^{11}$ COELHO, Fábio Ulhoa, O empresário e os direitos do consumidor. São Paulo: Saraiva, 1994. p. 237.

${ }^{12}$ PEREIRA, Marco Antonio Marcondes. Concorrência desleal por meio da publicidade. São Paulo: Juarez de Oliveira, 2001, p. 65.

${ }^{13}$ PASQUALOTTO, Adalberto. Os efeitos obrigacionais da publicidade no código de defesa do consumidor. São Paulo: Revista dos Tribunais, 1997, pp. 75-76.

${ }^{14}$ PEREIRA, Marco Antonio Marcondes. Concorrência desleal por meio da publicidade. São Paulo: Juarez de Oliveira, 2001, p. 65.
} 
se, a um só tempo, espaço para os organismos auto-regulamentares (como o CONAR e o Código Brasileiro de Autorregulamentação Publicitária), no Brasil e para o Estado (seja a administração pública, seja o Judiciário)"15.

A partir de 1990, portanto, é possível afirmar que a regulamentação da publicidade no Brasil, seguindo o modelo de boa parte dos países do mundo, passa a ser desconcentrada e mista - como bem explica Antonio Herman de Vasconcellos e Benjamin: "Desconcentrado por não haver uma centralização da regulamentação em um único órgão. Misto, por sua vez, devido à regulação efetuada tanto pelo Estado, como pelos próprios agentes

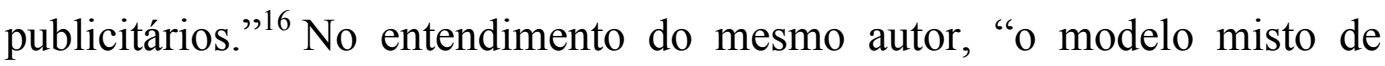
controle da publicidade parte do pressuposto de que a autorregulamentação não exerce autoridade suficiente e de que a atuação estatal, isoladamente, apresenta igualmente risco para o consumidor". ${ }^{17}$ Trata-se, portanto, "de modalidade que aceita e incentiva ambas as formas de controle, aquele executado pelo Estado e o outro a cargo dos partícipes publicitários". ${ }^{18}$

Ao comentar sobre o modelo misto de regulamentação da publicidade, Fábio Ulhoa Coelho chama a atenção para a importância do escopo de atuação da autorregulação publicitária:

A disciplina da publicidade não se esgota na questão de tutela do consumidor. Há outros aspectos da atividades publicitária que reclamam regramento jurídico, como os pertinentes às relações entre a agência, o veículo e o anunciante, a ética profissional, a relação quantitativa entre publicidade e programação de rádio e $\mathrm{TV}$, etc $^{19}$.

Enquanto o Código de Defesa do Consumidor e a regulamentação publicitária estatal como um todo estão mais preocupadas com a tutela do

\footnotetext{
${ }^{15}$ BENJAMIN, Antônio Herman de Vasconcellos e. In.: Ada Pellegrini Grinover [et al.] In Código Brasileiro de Defesa do Consumidor: comentado pelos autores do anteprojeto. Rio de Janeiro: Forense, 2001, p. 314.

${ }^{16}$ Ibid. pp. 264-266.

${ }^{17}$ BENJAMIN, Antônio Herman de Vasconcellos e. O controle jurídico da publicidade. Revista de Direito do Consumidor, São Paulo, n. 9, jan/mar. 1994, p. 52.

${ }^{18}$ BENJAMIN, Antônio Herman de Vasconcellos e. In.: Ada Pellegrini Grinover [et al.] In Código Brasileiro de Defesa do Consumidor: comentado pelos autores do anteprojeto. Rio de Janeiro: Forense, 2001, p. 314.

${ }^{19}$ COELHO, Fábio Ulhoa. Curso de Direito Comercial. São Paulo: Saraiva, 1998. V.1, p. 303.
} 
consumidor perante a publicidade, o sistema privado de autorregulação tem como finalidade primordial zelar pela ética na atividade publicitária - o que, no entanto, também resulta, direta ou indiretamente, na defesa dos interesses do consumidor. 


\section{O Conselho Nacional de Autorregulamentação Publicitária - CONAR}

\section{III.1. História}

O CONAR, como é conhecido o Conselho Nacional de Autorregulamentação Publicitária, órgão responsável pela autorregulação da publicidade no Brasil, é filho de um dos momentos mais delicados da história política do país. O ano era 1978 e o governo militar do Presidenteditador Ernesto Geisel, contradizendo sua tão propalada "abertura lenta, gradual e segura" não escondia o desejo em implementar mecanismos de controle e censura a toda e qualquer forma de publicidade em território nacional, inclusive criando uma autarquia para exercer controle prévio sobre a propaganda ${ }^{20}$.

Temendo por uma iminente ameaça de atentado à liberdade de expressão, que se tornava cada vez mais real, um rápido movimento de contra-ataque capitaneado pelos publicitários Mauro Salles e Caio Domingues conseguiu salvar a criativa e idiossincrática propaganda brasileira das canetas dos sádicos burocratas de Brasília.

Inspirados no modelo inglês de autorregulamentação, Salles e Domingues, auxiliados por outros grandes nomes da publicidade brasileira, como Petrônio Correa e Luiz Fernando Furquim de Campos, redigiram em 1978 o Código Brasileiro de Autorregulamentação Publicitária ${ }^{21}$ - que será detidamente analisado em capítulo posterior. Convicto de que a autorregulação seria a melhor e mais eficaz resposta ao desejo de ingerência do Estado sobre a propaganda, esse grupo notável de profissionais da comunicação articulou "longa e pacientemente o reconhecimento do Código pelas autoridades federais, convencendo-as a engavetar o projeto de

\footnotetext{
${ }^{20}$ BRITO, Judith. O consumidor não precisa de tutela. Disponível em: $<$ www.conar.org.br>. Acesso em 28 ago. 2013.

21 História - Contra a censura na publicidade. Disponível em <http://www.conar.org.br/>. Acesso em 28 ago. 2013.
} 
censura prévia e confiar que a própria publicidade brasileira era madura o bastante para se auto-regulamentar" 22 .

"Como garantia de que os compromissos assumidos no pacto seriam efetivamente cumpridos" ${ }^{23}$, dois anos mais tarde, em 1980, era dado um passo de suma importância no processo de implementação do sistema de autorregulação publicitária brasileira.

\begin{abstract}
Em maio de 1980 a ABAP (Associação Brasileira de Agências de Propaganda), a ABA (Associação Brasileira de Anunciantes), a ABERT (Associação Brasileira de Emissoras de Rádio e Televisão), a ANJ (Associação Nacional de Jornais), os maiores editores de revistas e a Central de Outdoor reúnem-se em assembleia e formalizam a criação da Conar, cujo quadro social aglutina agências, veículos e anunciantes de todo o país. Em 20 de outubro do mesmo ano, em Assembleia Geral Extraordinária, os mesmos associados deliberam coverter a Conar no Conar - Conselho Nacional de Autorregulamentação Publicitária ${ }^{24}$.
\end{abstract}

Nascia o CONAR. A propaganda brasileira voltava a respirar aliviada.

\title{
III.2. Considerações preliminares
}

O CONAR é o responsável pela físcalização dos aspectos éticos e morais de toda a publicidade veiculada em território brasileiro, e "tem como objetivo principal o de aplicar o Código Nacional de Autorregulamentação Publicitária, protegendo, assim, a concorrência e os consumidores indiretamente" 25 .

Além de ser um órgão célere e especializado, o CONAR também representa um mecanismo gratuito para o consumidor que se sentir lesado perante a publicidade de algum produto ou serviço. De qualquer forma,

\footnotetext{
${ }^{22}$ História - Contra a censura na publicidade. Disponível em $<$ http://www.conar.org.br $>$. Acesso em 28 ago. 2013.

${ }^{23}$ ARRUDA, Maria Cecilia Coutinho de. A Ética na Propaganda. Escola de Administração de Empresas de São Paulo, Fundação Getúlio Vargas, NPP, Núcleo de Pesquisas e Publicações, 1995, p. 35 .

${ }^{24}$ SCHNEIDER, ARI. CONAR 25 anos: ética na prática. São Paulo: Terceiro Nome, 2005, p. 60.

${ }^{25}$ PEREIRA, Marco Antonio Marcondes. Concorrência desleal por meio da publicidade. São Paulo: Juarez de Oliveira, 2001, p. 72.
} 
muitos autores, principalmente os doutrinadores de direito do consumidor, fazem críticas à existência e atuação do CONAR. São questionamentos comuns, aliás, à maioria dos sistemas autorreguladores. Antonio Herman de Vasconcellos e Benjamin discorre sobre as principais objeções:

Em primeiro lugar, a regra de autodisciplina não vincula todos os operadores, limitando-se àqueles que aderem, voluntariamente, a tal modalidade de controle. Ademais, as regras de auto-regulamentação não são normas jurídicas, faltandolhes, por isso mesmo, a qualidade de generalidade, obrigando somente os aderentes, isto é, opera tão-só no plano normativo interno. Nenhuma relevância externa é conferida às regras de um tal ordenamento.

Em terceiro lugar, um tal sistema - em oposição ao estatal, fundado na autoridade - apresenta-se como mera derivação contratual. Sua força vinculante, é portanto, inferior à do modelo público.

Além disso, o controle não se faz pelo ângulo do consumidor, mas agregando-se a preocupações dessa natureza outras que pouco têm a ver com ele, na sua posição de parte vulnerável no mercado, como aquelas relativas à concorrência leal e à moralidade 26 .

Adalberto Paqualotto ainda complementa, em poucas linhas, com talvez a principal crítica à autorregulamentação publicitária: "o problema é que as decisões do CONAR são de cumprimento espontâneo. Os estatutos da entidade não lhe outorgam nenhum poder coativo - e, de qualquer modo, esse poder sempre seria limitado, por se tratar de sociedade privada" ${ }^{27}$.

No que pese a pertinência de alguns argumentos, a praxis e a realidade desmentem a maior parte destes. As estatísticas atestam que as decisões proferidas pelo Conselho de Ética do CONAR possuem níveis altíssimos de aceitação e cumprimento. Em sua obra Publicidade e Direito, Lucia Ancona Lopez de Magalhães Dias registra palestra proferida pelo presidente do CONAR, Gilberto Leifert, na qual este afirma que, nos mais de trinta anos de existência da entidade, apenas sete decisões não foram

\footnotetext{
${ }^{26}$ BENJAMIN, Antônio Herman de Vasconcellos e. In.: Ada Pellegrini Grinover [et al.] In Código Brasileiro de Defesa do Consumidor: comentado pelos autores do anteprojeto. Rio de Janeiro: Forense, 2001, pp. 313-314.

${ }^{27}$ PASQUALOTTO, Adalberto. Os efeitos obrigacionais da publicidade no código de defesa do consumidor. São Paulo: Revista dos Tribunais, 1997, p. 68.
} 
cumpridas. Todas estas, por sinal, tendo sido levadas ao Poder Judiciário, tiveram os seus entendimentos confirmados ${ }^{28}$.

No mesmo sentido, Ari Schneider afirma, sobre o CONAR, que “desde a sua criação, já instaurou mais de 5 mil processos éticos e promoveu um sem-número de conciliações entre associados em conflito. Nunca foi desacatado pelos veículos de comunicação e saiu vitorioso nas poucas vezes que foi questionado na Justiça." 29 Fica evidente, portanto, que "os julgamentos, de fato, exercem grande força moral sobre aqueles os quais voluntariamente aderiram à associação autorreguladora de publicidade",30.

E, no que diz respeito à outra frequente crítica de doutrinadores consumeristas, ainda que a sua atuação represente inegavelmente um mecanismo de fácil acesso para o consumidor, o CONAR não tem a pretensão, e muito menos os meios e poderes necessários para tanto, de ser o principal defensor dos direitos do consumidor. Afinal, para isto existe o Código de Defesa do Consumidor.

\section{III.3. Composição e funcionamento}

O CONAR é uma sociedade civil sem fins lucrativos, conforme dispõe o art. $1^{\mathrm{o}}$ do seu estatuto social ${ }^{31}$.

Nas palavras de Maria Cecília Coutinho de Arruda:

\footnotetext{
${ }^{28}$ MAGALHÃES DIAS, Lucia Ancona Lopez de. Publicidade e Direito. São Paulo: RT, 2010, p. 43.

${ }^{29}$ SCHNEIDER, ARI. CONAR 25 anos: ética na prática. São Paulo: Terceiro Nome, 2005, p. 61.

${ }^{30}$ PERES, Lucas da Silva. O tratamento autorregulamentar da publicidade abusiva que fere $o$ “princípio geral da decência. Ribeirão Preto. 2012. p. 79. Monografia - Universidade de São Paulo - Faculdade de Direito de Ribeirão Preto.

${ }^{31}$ Artigo $1^{\circ}$. O CONSELHO NACIONAL DE AUTO-REGULAMENTAÇÃO PUBLICITÁRIA CONAR, fundado na Cidade de São Paulo, em 5 de maio de 1980, é uma sociedade civil sem fins lucrativos.
} 
O Conar se propõe ao desenvolvimento de normas, sua divulgação para os interessados, orientação pré-publicitária, monitoria de cumprimento de padrões, atendimento às reclamações e a reprovação de comportamento conflitante com as normas, incluindo a divulgação de suas decisões e outras ações ${ }^{32}$.

Nos termos do art. $5^{\circ}$ do Estatuto Social do CONAR:
Artigo $\quad 5^{\circ}$
$5^{\circ}$. São
finalidades
do
CONAR:

I. Zelar pela comunicação comercial, sob todas as formas de propaganda, fazendo observar as normas do Código Brasileiro de Autorregulamentação Publicitária, que prevalecerão sobre quaisquer outras. II. Funcionar como órgão judicante nos litígios éticos que tenham por objeto a indústria da propaganda ou questões a ela relativas. III. Oferecer assessoria técnica sobre ética publicitária aos seus associados, aos consumidores em geral e às autoridades públicas, sempre que solicitada.

IV. Divulgar os princípios e normas do Código Brasileiro de Autorregulamentação Publicitária, visando a esclarecer a opinião pública sobre a sua atuação regulamentadora de normas éticas aplicáveis à publicidade comercial, assim entendida como toda a atividade destinada a estimular o consumo de bens e serviços, bem como promover instituições, conceitos e ideias. V. Atuar como instrumento de concórdia entre veículos de comunicação e anunciantes, e salvaguarda de seus interesses legítimos e dos consumidores. VI. Promover a liberdade de expressão publicitária e a defesa das prerrogativas constitucionais da propaganda comercial.

\section{Qualquer um pode oferecer reclamação escrita ou verbal ao CONAR} - consumidores, autoridades, os seus próprios associados, etc. - desde que a queixa não seja anônima. O CONAR pode, inclusive, agir ex officio, instaurando um processo independentemente de provação, sempre que reputar irregular uma propaganda. Conforme explica ARI SCHNEIDER:

Pode recorrer ao Conar toda pessoa que se sinta ofendida por uma peça publicitária - um filme de televisão, spot de rádio, anúncio de revista, jornal, outdoor, internet, mala direta ou cartaz de ponto de venda. Ou que tenha constatado que o anunciante não cumpriu com o prometido no anúncio, que a peça não corresponde à verdade ou, ainda, fere os princípios da leal concorrência ${ }^{33}$.

Quando o denunciante for um consumidor, a denúncia não importará em nenhum ônus. No entanto, "o anunciante que quiser processar o

\footnotetext{
${ }^{32}$ ARRUDA, Maria Cecilia Coutinho de. A Ética na Propaganda. Escola de Administração de Empresas de São Paulo, Fundação Getúlio Vargas, NPP, Núcleo de Pesquisas e Publicações, 1995, p. 36.

${ }^{33}$ SCHNEIDER, ARI. CONAR 25 anos: ética na prática. São Paulo: Terceiro Nome, 2005, p. 65.
} 
concorrente precisa ser associado ao CONAR, estar comprometido com o cumprimento do código e contribuir para a manutenção do órgão" ${ }^{\prime 34}$. Desta forma, o CONAR é "mantido pela contribuição das principais entidades da publicidade brasileira e seus filiados - anunciantes, agências e veículos." 35 É muito importante observar que "em nenhuma hipótese o Conar exerce censura prévia sobre peças de propaganda". "Suas intervenções ocorrem em anúncios que estão sendo veiculados e a efetividade de suas decisões resulta, em larga medida, da disposição permanente dos veículos de acatar incondicionalmente as recomendações do Conselho de Ética" ${ }^{\text {37 }}$. Ou seja, no que tange à autorregulação publicitária, não há de se falar de forma alguma em controle a priori.

O art. 50 do Código Brasileiro de Autorregulamentação Publicitária (CBAP) prevê as sanções que podem ser impostas pelo CONAR. São estas: advertência; recomendação de alteração ou correção do anúncio; recomendação aos veículos no sentido de que sustem a divulgação do anúncio; e, divulgação da posição do CONAR com relação ao anunciante, à agência e ao veículo, através de veículos de comunicação, em face do nãoacatamento das medidas e providências preconizadas.

\section{III.3.1. Conselho de Ética}

O Conselho de Ética é o "órgão soberano na fiscalização, julgamento e deliberação no que se relaciona à obediência e cumprimento do código"38. Utilizando-se o modelo parlamentarista de separação de poderes de Montesquieu como metáfora, o Conselho de Ética seria o poder judiciário do sistema autorregulador ${ }^{39}$. Composto por 130 conselheiros, dentre os

\footnotetext{
${ }^{34}$ Ibid, p. 66.

${ }_{35}^{35}$ Missão do Conar. Disponível em <http://www.conar.org.br/>. Acesso em 25 ago. 2013.

${ }^{36}$ SCHNEIDER, ARI. CONAR 25 anos: ética na prática. São Paulo: Terceiro Nome, 2005, p. 65.

${ }^{37}$ Código Brasileiro de Autorregulamentação Publicitária - Edição de 30 anos. São Paulo: 2008.

${ }^{38}$ SCHNEIDER, ARI. CONAR 25 anos: ética na prática. São Paulo: Terceiro Nome, 2005, p. 65.

${ }^{39}$ Ibid, p. 65.
} 
quais representantes da sociedade civil e das agências de publicidade, dos anunciantes e dos veículos de comunicação, nos termos do art. 42 do Estatuto Social do CONAR:

Artigo 42. Compete ao Conselho de Ética do Conar: I. Receber, processar e julgar as representações por infração ao Código Brasileiro de Auto-Regulamentação Publicitária e seus recursos, observadas as disposições deste estatuto e do R.I.C.E. - Regimento Interno do Conselho de Ética. II. Atuar como mediador entre anunciantes, entre agências, entre aqueles e estas e os veículos de comunicação, em todos os casos de disputa, promovendo tentativas de conciliação das partes. III. Aplicar as medidas e providências previstas no Código Brasileiro de AutoRegulamentação Publicitária aos infratores das normas nele estabelecidas. IV. Aprovar as súmulas da jurisprudência firmada, bem como deliberar sobre sua alteração e cancelamento, mediante proposta formal de qualquer de seus membros ou Diretor Executivo.

Internamente, o Conselho de Ética é composto por:

(i) O Plenário e seu presidente;

(ii) A Câmara Especial de Recursos e seu presidente;

(iii) As Câmaras de Ética - três em São Paulo, uma no Rio de Janeiro, uma em Brasília e uma em Porto Alegre - e seus respectivos presidentes.

Ari Schneider explica que "cabe ao Plenário julgar os recursos extraordinários, uniformizar a jurisprudência quando houver divergências e aprovar as súmulas de jurisprudência firmadas pelo Conselho de Ética." ${ }^{40}$ Já a Câmara Especial, obedecendo ao disposto no art. $4^{\circ}$ do Regimento Interno do Conselho de Ética tem a função de "julgar os recursos ordinários interpostos contra decisões das Câmaras de Ética"41, as quais, por sua vez, “compete julgar originariamente os processos instaurando por infração ao código, decidindo as medidas liminares de sustação eventualmente deferidas." 42

\footnotetext{
${ }^{40}$ SCHNEIDER, ARI. CONAR 25 anos: ética na prática. São Paulo: Terceiro Nome, 2005, p. 68.

${ }^{41}$ Artigo $4^{\circ}-$ É atribuição da Câmara Especial de Recursos julgar os Recursos Ordinários interpostos contra decisões das Câmaras.

${ }^{42}$ SCHNEIDER, ARI. CONAR 25 anos: ética na prática. São Paulo: Terceiro Nome, 2005, p. 68.
} 


\section{III.3.1.1. Processo éticos no CONAR}

Nos termos do art. 14 do Regimento Interno do Conselho de Ética (RICE), os processos éticos no CONAR podem ser de dois tipos: investigatórios ou contenciosos. Como não poderia deixar de ser, em se tratando de um órgão autorregulador, o rito processual do CONAR é extremamente rápido e simplificado. Nas palavras de Ari Schneider:

Formulada a denúncia e verificada a sua procedência, a diretoria do Conar sorteia um relator. $\mathrm{O}$ anunciante é informado da denúncia e pode enviar defesa por escrito. As partes envolvidas podem comparecer às reuniões e apresentar seus argumentos perante os conselheiros. Encerrados os debates, o relator apresenta seu parecer, que é levado a votação. A decisão é imediatamente comunicada às partes e, se for o caso, aos veículos de comunicação ${ }^{43}$.

Os processos investigatórios são sigilosos (art. 21 do RICE) e os contenciosos, em regra, públicos. No entanto, os processos contenciosos serão sigilosos "quando o despacho que autorizar o processamento assim o determinar, por razão de segredo de indústria; por ausência de interesse direto do consumidor; ou, ainda, em caso de suspensão voluntária do anúncio pela agência ou anunciante, até final decisão do Conselho de Ética" ${ }^{44}$.

$\mathrm{O}$ art. 20 do RICE determina o prazo de cinco dias úteis para a defesa do denunciado, contados a partir da juntada aos autos do documento que comprove a citação, "operando-se a confissão no caso de revelia"

Caso não se configure nenhuma das hipóteses de aplicação das sanções previstas no art. 50 do CBAP, e se houver perda de objeto, desistência expressa do interessado, ou conciliação, a representação será arquivada. Aliás, "a conciliação dos envolvidos em procedimentos do CONAR é muito comum, sendo estimulada pelo órgão julgador, e

\footnotetext{
${ }^{43}$ Ibid, p. 65.

${ }^{44}$ PEREIRA, Marco Antonio Marcondes. Concorrência desleal por meio da publicidade. São Paulo: Juarez de Oliveira, 2001, p. 74.

${ }^{45}$ Ibid, p. 75.
} 
representa amadurecimento dos anunciantes, senão da própria sociedade, em defesa da autorregulamentação" ${ }^{, 46}$.

Conforme o disposto no art. 29 do RICE, "a concessão de medida liminar em processos do CONAR é possível por membro do Conselho de Ética, de ofício ou a pedido, para recomendação de imediata suspensão da veiculação do anúncio em desacordo com o Código. ${ }^{, 47}$ Marco Antonio Marcondes Pereira explica que a liminar é cabível para:

Evitar ineficácia de possível decisão futura que recomende a sustação da publicidade; em caso de clamor social prejudicial à ética da propaganda comercial; na hipótese da publicidade ser objeto de reprovação sumulada pelo CONAR; e, finalmente, no caso da publicidade já ter sido reprovada pelo CONAR em julgamento anterior (art. 30, RICE) $)^{48}$.

Nos termos do art. 37 do RICE, "denomina-se acórdão a decisão proferida em sessão de julgamento do Plenário e das Câmaras e despacho a decisão proferida pelos Presidentes do CONAR, das Câmaras, ou Relator e do Diretor Executivo."

\section{III.3.3. Conselho Superior}

De volta à metáfora da tripartição de poderes preconizada por Montesquieu, o Conselho Superior seria o poder legislativo ${ }^{49}$. Responsável direto pela "função autorregulamentadora propriamente dita", cabe ao Conselho Superior fixar as normas éticas que a propaganda comercial brasileira se compromete voluntariamente a observar e praticar.

$\mathrm{Na}$ lição de Maria Cecília Coutinho de Arruda, o Conselho Superior tem, portanto, "como principais funções normativas o desenvolvimento e a alteração do Código e a aprovação do regimento interno do Conselho de

\footnotetext{
${ }^{46}$ Ibid, p. 75.

${ }^{47}$ Ibid, p. 75.

${ }^{48}$ Ibid, p. 75.

${ }^{49}$ SCHNEIDER, ARI. CONAR 25 anos: ética na prática. São Paulo: Terceiro Nome, 2005, p. 66.
} 
Ética." ${ }^{, 50}$ Mais do que isso, é também o "responsável por fixar os programas e planejar as ações que serão executadas pela diretoria, orientar a política de relações externas da instituição, votar orçamentos, aprovar prestações de contas e encaminhas propostas à Assembleia Geral" ${ }^{51}$.

${ }^{50}$ ARRUDA, Maria Cecilia Coutinho de. A Ética na Propaganda. Escola de Administração de Empresas de São Paulo, Fundação Getúlio Vargas, NPP, Núcleo de Pesquisas e Publicações, 1995, p. 36.

${ }^{51}$ SCHNEIDER, ARI. CONAR 25 anos: ética na prática. São Paulo: Terceiro Nome, 2005, p. 67. 


\section{O Código Brasileiro de Autorregulamentação Publicitária e decisões do CONAR}

\section{IV.1. O Código Brasileiro de Autorregulamentação Publicitária (CBAP)}

Aprovado no III Congresso Brasileiro de Propaganda, realizado em 1978, o Código Brasileiro de Autorregulamentação Publicitária (CBAP) é o principal instrumento normativo utilizado pelo CONAR na aplicação de suas decisões. Através de 50 artigos e 19 anexos, o documento disciplina as normas éticas que devem ser obedecidas pelos anunciantes e agências de publicidade na elaboração de seus anúncios ${ }^{52}$.

É importante observar que a propaganda política não é objeto passível da autorregulamentação publicitária. O art. 11 do CBAP é expresso neste sentido: “A propaganda política e a político-partidária não são capituladas neste Código". No entanto, consoante ao art. 12 do mesmo código, a publicidade governamental e de demais órgãos e empresas estatais não está fora da esfera de atuação do $\operatorname{CONAR}^{53}$. Também não são abrangidos pela esfera de atuação do CONAR as atividades de relações públicas e "os eventos realizados com o fim de promover a campanha publicitária, envolvendo a apresentação do trabalho publicitário a pessoas determinadas e atraindo a atenção dos meios de comunicação, conhecidos como publicity" ${ }^{, 54}$.

\footnotetext{
${ }^{52}$ O que é o Código de Autorregulamentação Publicitária. Disponível em: $<$ http://www.conar.org.br/>. Acesso em 30 ago. 2013.

${ }^{53}$ Artigo 12. A publicidade governamental, bem como a de empresas subsidiárias, autarquias, empresas públicas, departamentos, entidades paraestatais, sociedades de economia mista e agentes oficiais da União, dos Estados, dos Territórios, dos Municipios e do Distrito Federal, salvo proibição legal, deve se conformar a este Código da mesma forma que a publicidade realizada pela iniciativa privada.

${ }^{54}$ PEREIRA, Marco Antonio Marcondes. Concorrência desleal por meio da publicidade. São Paulo: Juarez de Oliveira, 2001, p. 71.
} 


\section{IV.2. Os princípios gerais do CBAP e casos julgados pelo CONAR}

O Capítulo II do CBAP, que engloba os artigos 19 a 43, contém os princípios gerais que norteiam e regulamentam a publicidade nacional. $\mathrm{Na}$ grande maioria das vezes, são estes artigos que embasam os casos julgados no CONAR.

Algumas normas do CBAP, principalmente aquelas contidas no capítulo dos princípios gerais, em muito se assemelham às dispos referentes à publicidade presentes no Código de Defesa do Consumidor. Tendo sido elaborado mais de uma década após o diploma autorregulador, fica clara a influência axiológica do CBAP sobre o legislador consumerista.

Além dos princípios gerais, o CBAP contém mais de vinte anexos com regras específicas para determinadas categorias de anúncios, como bebidas alcóolicas, produtos de fumo e inibidores de fumo, produtos farmacêuticos populares, e imóveis.

\section{IV.2.1. Respeitabilidade}

Os três artigos que inauguram o capítulo referente aos princípios gerais do CBAP dizem respeito à necessidade de observância da respeitabilidade na publicidade.

Artigo 19. Toda atividade publicitária deve caracterizar-se pelo respeito à dignidade da pessoa humana, à intimidade, ao interesse social, às instituições e símbolos nacionais, às autoridades constituídas e ao núcleo familiar.

Artigo 20. Nenhum anúncio deve favorecer ou estimular qualquer espécie de ofensa ou discriminação racial, social, política, religiosa ou de nacionalidade.

Artigo 21. Os anúncios não devem conter nada que possa induzir a atividades criminosas ou ilegais - ou que pareça favorecer, enaltecer ou estimular tais atividades. 
Estes dispositivos estão em perfeita consonância com a Constituição Federal, especialmente quanto ao princípio da dignidade da pessoa humana ${ }^{55}$.

A infração ao princípio da respeitabilidade é causa frequente para o ajuizamento de representações no CONAR. Em março de 2012, no julgamento da Representação 041/12 ${ }^{56}$, o CONAR decidiu pela sustação de um filme comercial da Red Bull, alvo da denúncia de muitos consumidores que alegaram ofensa ao princípio da respeitabilidade e discriminação religiosa por parte do anunciante. A propagada, que também foi suspensa na África do $\mathrm{Sul}^{57}$, mostra uma animação de Jesus andando sobre as águas. Os apóstolos que o acompanham num barco perguntam se ele o faz por ter ingerido a bebida ou por se tratar de milagre, ao que Jesus responde: "Você só tem de ficar esperto aonde tem pedra" ${ }^{58}$. A relatora propôs a alteração do anúncio. No entanto, tendo a representação sido levada ao plenário, os conselheiros decidiram pela sustação da peça, alegando não verem como que a simples alteração do filme poderia eliminar as infrações éticas.

Caso emblemático julgado pelo CONAR, e que também envolve o princípio da respeitabilidade e a religião católica é o da Representação 177/91, de $1991^{59}$. A marca italiana de roupas Benetton veiculou, em revistas e outdoors, anúncio que mostrava um padre e uma freira se beijando, com a assinatura "United Colors of Benetton”. Fundamentando-se

\footnotetext{
${ }^{55} \mathrm{CF}$, Art. $1^{\circ} \mathrm{A}$ República Federativa do Brasil, formada pela união indissolúvel dos Estados e Municípios e do Distrito Federal, constitui-se em Estado Democrático de Direito e tem como fundamentos:

(...)

III - a dignidade da pessoa humana.

${ }^{56}$ Casos CONAR - Decisões Março/2012. Disponível em <http://www.conar.org.br>. Acesso em 08 out. 2013.

57 AZEVEDO, Reinaldo. Cristo e o Red Bull. Ou: Maomé jamais apareceria tomando um energético. 30 mar. 2012. Blog Reinaldo Azevedo - Veja. Disponível em

$<$ http://veja.abril.com.br/blog/reinaldo/geral/cristo-e-o-red-bull-ou-maome-jamais-apareceriatomando-um-energetico/>. Acesso em 08 out. 2013.

${ }^{58}$ Casos CONAR - Decisões Março/2012. Disponível em <http://www.conar.org.br>. Acesso em 08 out. 2013.

${ }^{59}$ Casos CONAR - Decisões 1991. Disponível em <http://www.conar.org.br>. Acesso em 08 out 2013.
} 
nos artigos $1^{\mathrm{o} 60}$ e 20, inúmeros consumidores católicos apresentaram queixa contra a peça publicitária. Instaurada a representação, a empresa, em sua defesa, alegou que o anúncio, "embora exibindo o beijo entre dois representantes da religião católica, não sugeriu volúpia, lascívia ou erotismo. Ao contrário, representava a afeição e o carinho em sua acepção mais fraterna" ${ }^{\prime 61}$. E, por isso, não restaria caracterizada qualquer ofensa ou desrespeito à religião católica.

Em primeira instância, decidiu-se de forma unânime pelo arquivamento da representação. No entanto, este entendimento foi revisto na Câmara Especial de Recursos, que decidiu por maioria dos votos pela sustação do anúncio. O Recurso Extraordinário, levado a julgamento pelo plenário do Conselho de Ética, foi relatado pelo conselheiro Ricardo Rodrigues Pereira. Em extenso voto, no qual foi acompanhado pela maioria dos conselheiros presentes, o relator decidiu pela sustação da peça:

Temos um compromisso maior com o povo brasileiro e um respeito profundo pelo Conar. E não há dúvida que esta campanha publicitária, que utilizou o padre e a freira, atingiu duramente o modo de ser, a educação e o respeito que primam em nosso país. As manifestações internacionais dão conta de que reações diversas aconteceram em outros países. Achamos que é hora de, via Conar, o país mostrar que tem compromissos com a moral, com a verdade e com o respeito aos outros. (...) Em face do exposto e considerando que os consumidores queixosos têm direito a uma resposta conclusiva, entende este relator que faltou sensibilidade à empresa anunciante, utilizando uma comunicação de forma abusiva e incomum, cujo único objetivo foi o de impactar a opinião pública com a mensagem publicitária; e sugere que sejam aplicadas as hipóteses previstas nas letras "a" e "c", do artigo 50, ou seja a advertência do anunciante e a sustação da veiculação dos anúncios ${ }^{62}$.

Como corolários do princípio da respeitabilidade, o CBAP também dispõe sobre a necessidade de observação da decência e da proteção da intimidade, em seus artigos 22 e 34, respectivamente:

\footnotetext{
${ }^{60}$ Artigo 1o. Todo anúncio deve ser respeitador e conformar-se às leis do país; deve, ainda, ser honesto e verdadeiro.

${ }^{61}$ Casos CONAR - Decisões 1991. Disponível em <http://www.conar.org.br>. Acesso em 08 out 2013.

62 Casos CONAR - Decisões 1991. Disponível em <http://www.conar.org.br>. Acesso em 08 out 2013.
} 
Artigo 22. Os anúncios não devem conter afirmações ou apresentações visuais ou auditivas que ofendam os padrões de decência que prevaleçam entre aqueles que a publicidade poderá atingir.

Artigo 34. Este Código condena a publicidade que:

a. faça uso de imagens ou citações de pessoas vivas, a menos que tenha sido obtida sua prévia e expressa autorização;

b. ofenda as conviç̧ões religiosas e outras suscetibilidades daqueles que descendam ou sejam de qualquer outra forma relacionados com pessoas já falecidas cuja imagem ou referência figure no anúncio;

c. revele desrespeito à dignidade da pessoa humana e à instituição da família;

d. desrespeite a propriedade privada e seus limites.

Com fulcro no art. 22, a Representação n. $238 / 09^{63}$ foi aberta após dezenas de queixas de consumidores contra peça publicitária da São Paulo Alpargatas. O comercial "Avó”, das sandálias Havaianas, mostra o diálogo entre uma avó e uma neta em um restaurante ${ }^{64}$. Ao criticar o fato de a neta estar usando um chinelo no ambiente, a jovem retruca: "Deixa de ser atrasada, vó. Isso não é chinelo, é Havaianas.”. Em seguida, o ator Cauã Reymond entra no restaurante, e a avó diz que a neta deveria "arranjar um rapaz assim". A neta, por sua vez, comenta que deve ser muito chato casar com um famoso. No que a simpática senhora rebate: "Mas quem falou em casamento? Estou falando em sexo." Surpresa com o espanto da neta pelo comentário, ela ainda arremata: "E depois eu que sou atrasada?".

Em síntese, as denúncias basearam-se em uma suposta violação do princípio da decência, na medida em que a avó estaria estimulando a neta à prática de ato sexual sem compromisso e sem mencionar a proteção necessária. Também de acordo com as denúncias, "o comercial seria inadequado por constituir apelo excessivamente malicioso e contrário aos valores sócio-educativos $" 65$. Em sua defesa, o anunciante e a agência responsável pelo comercial, a AlmapBBDO, rebateram as denúncias alegando que a avó é colocada numa situação em que representa a modernidade e que, por isso, surpreende, na medida em que teria uma

\footnotetext{
${ }^{63}$ Casos CONAR - Decisões Novembro/2009. Disponível em $<$ http://www.conar.org.br $>$. Acesso em 08 out 2013.

${ }^{64}$ Filme "Avó" com Cauã Reymond - Havaianas. Disponível em $<$ http://www.youtube.com/watch?v=KxgTJMZo8Kg>. Acesso em 08 out. 2013.

${ }^{65}$ Casos CONAR - Decisões Novembro/2009. Disponível em $<$ http://www.conar.org.br $>$. Acesso em 08 out 2013.
} 
postura condizente com o comportamento do público jovem e adulto contemporâneo. Afirmaram ainda que "a publicidade em questão segue a linha de comunicação de Havaianas, que privilegia o bom humor, a diversão e a surpresa, sempre reservada para o final das mensagens."

$\mathrm{O}$ relator da representação reconheceu que a peça publicitária em questão é criativa, bem humorada e que está em sintonia com o comportamento da maioria do público. No entanto, observou a necessidade de se respeitar a preocupação dos consumidores que sentiram-se incomodados com o anúncio. O relator votou pela alteração do horário da veiculação, para que esta restrinja-se à programação adulta, e teve o seu entendimento acatado pela maioria do Conselho de Ética.

\section{IV.2.2. Honestidade e Apresentação Verdadeira}

Os princípios da honestidade e da apresentação verdadeira são corolários do princípio da veracidade. Segundo este, "toda mensagem publicitária disseminada ao público deve conter afirmações que não venham enganar o público, influenciando-o além dos limites convencionais da publicidade e auferindo ganhos concorrenciais indevidos com base em erro dos consumidores" ${ }^{967}$. A apreciação de casos envolvendo os princípios da honestidade e da apresentação verdadeira é bastante comum no CONAR.

O princípio da honestidade encontra-se previsto no art. 23 do CBAP:

Artigo 23. Os anúncios devem ser realizados de forma a não abusar da confiança do consumidor, não explorar sua falta de experiência ou de conhecimento e não se beneficiar de sua credulidade.

\footnotetext{
${ }^{66}$ Casos CONAR - Decisões Novembro/2009. Disponível em $<$ http://www.conar.org.br $>$. Acesso em 08 out 2013.

${ }^{67}$ PEREIRA, Marco Antonio Marcondes. Concorrência desleal por meio da publicidade. São

Paulo: Juarez de Oliveira, 2001, p. 80
} 
Na Representação n. 289/04 ${ }^{68}$, a Toyota contestou anúncio da Hyundai no qual a montadora sul coreana afirma ser líder de mercado e ter ultrapassado em qualidade os seus concorrentes. Alegando infração ao princípio da honestidade, a denunciante considerou inverídicas e distorcidas as informações apresentadas, na medida em que a Hyundai venceu apenas uma das dezoito categorias pesquisadas e que esta pesquisa era voltada para o mercado dos Estados Unidos. Em sua defesa, a Hyundai "diz ter refletido no anúncio o resultado da pesquisa e comparado a qualidade como um todo das montadoras, no que defende ter tido um resultado qualitativo melhor do que suas concorrentes"69. Ao julgar a representação, o relator apontou a clara falta de honestidade e verdade do anúncio, explicitada pela edição da pesquisa, para recomendar a sustação da peça.

No mesmo sentido do princípio da honestidade, o CBAP também preza pela apresentação verdadeira na propaganda, de acordo com os detalhados termos do art. 27:

Artigo 27. O anúncio deve conter uma apresentação verdadeira do produto oferecido, conforme disposto nos artigos seguintes desta Seção, onde estão enumerados alguns aspectos que merecem especial atenção.

$\S 1^{\circ}$ - Descrições

No anúncio, todas as descrições, alegações e comparações que se relacionem com fatos ou dados objetivos devem ser comprobatórias, cabendo aos Anunciantes e Agências fornecer as comprovações, quando solicitadas.

$\S 2^{\circ}$ - Alegações

O anúncio não deverá conter informação de texto ou apresentação visual que direta ou indiretamente, por implicação, omissão, exagero ou ambigüidade, leve o Consumidor a engano quanto ao produto anunciado, quanto ao Anunciante ou seus concorrentes, nem tampouco quanto a:

a. natureza do produto (natural ou artificial);

b. procedência (nacional ou estrangeira);

c. composição;

d. finalidade.

$\S 3^{\circ}$ - Valor, Preço, Condições

$\mathrm{O}$ anúncio deverá ser claro quanto a:

a. valor ou preço total a ser pago pelo produto, evitando comparações irrealistas ou exageradas com outros produtos ou outros preços; alegada a sua redução, o Anunciante deverá poder comprová-la mediante anúncio ou documento que evidencie o preço anterior;

\footnotetext{
${ }^{68}$ Casos CONAR - Decisões Janeiro/2005. Disponível em $<$ http://www.conar.org.br $>$. Acesso em 19 set. 2013.

${ }^{69}$ Casos CONAR - Decisões Janeiro/2005. Disponível em $<$ http://www.conar.org.br $>$. Acesso em 19 set. 2013.
} 
b. entrada, prestações, peculiaridades do crédito, taxas ou despesas previstas nas operações a prazo;

c. condições de entrega, troca ou eventual reposição do produto;

d. condições e limitações da garantia oferecida.

$\S 4^{\circ}$ - Uso da Palavra "Grátis"

a. O uso da palavra "grátis" ou expressão de idêntico significado só será admitido no anúncio quando não houver realmente nenhum custo para o Consumidor com relação ao prometido gratuitamente;

b. nos casos que envolverem pagamento de qualquer quantia ou despesas postais, de frete ou de entrega ou, ainda, algum imposto, é indispensável que o Consumidor seja esclarecido.

$\S 5^{\circ}$ - Uso de Expressões Vendedoras

O uso de expressões como "direto do fabricante", "preço de atacado", "sem entrada" e outras de igual teor não devem levar o consumidor a engano e só serão admitidas quando o Anunciante ou a Agência puderem comprovar a alegação.

$\S 6^{\circ}$ - Nomenclatura, Linguagem, "Clima"

a. $\mathrm{O}$ anúncio adotará o vernáculo gramaticalmente correto, limitando o uso de gíria e de palavras e expressões estrangeiras, salvo quando absolutamente necessárias para transmitir a informação ou o "clima" pretendido. Todavia, esta recomendação não invalida certos conceitos universalmente adotados na criação dos anúncios e campanhas. O primeiro deles é que a publicidade não se faz apenas com fatos e idéias, mas também com palavras e imagens; logo, as liberdades semânticas da criação publicitária são fundamentais. O segundo é que a publicidade, para se comunicar com o público, tem que fazer uso daquela linguagem que o Poeta já qualificou como "Língua errada do povo / Língua certa do povo / Porque ele é que fala gostoso / o Português no Brasil";

b. na publicidade veiculada pelo Rádio e pela Televisão, devem os Anunciantes, Agências e Veículos zelar pela boa pronúncia da língua portuguesa, evitando agravar os vícios de prosódia que tanto já estão contribuindo para desfigurar o legado que recebemos de nossos antepassados;

c. todo anúncio deve ser criado em função do contexto sócio-cultural brasileiro, limitando-se o mais possível a utilização ou transposição de contextos culturais estrangeiros;

d. o anúncio não utilizará o calão;

e. nas descrições técnicas do produto, o anúncio adotará a nomenclatura oficial do setor respectivo e, sempre que possível, seguirá os preceitos e as diretrizes da Associação Brasileira de Normas Técnicas - ABNT e do Instituto Nacional de Metrologia, Normalização e Qualidade Industrial - INMETRO.

$\S 7^{\circ}$ - Pesquisas e Estatísticas

a. o anúncio não se referirá a pesquisa ou estatística que não tenha fonte identificável e responsável;

b. o uso de dados parciais de pesquisa ou estatística não deve levar a conclusões distorcidas ou opostas àquelas a que se chegaria pelo exame do total da referência.

$\S 8^{\circ}$ - Informação Científica

O anúncio só utilizará informação científica pertinente e defensável, expressa de forma clara até para leigos.

$\S 9^{\circ}$ - Testemunhais

a. $\mathrm{O}$ anúncio abrigará apenas depoimentos personalizados e genuínos, ligados à experiência passada ou presente de quem presta o depoimento, ou daquele a quem o depoente personificar;

b. o testemunho utilizado deve ser sempre comprovável;

c. quando se usam modelos sem personalização, permite-se o depoimento como "licença publicitária" que, em nenhuma hipótese, se procurará confundir com um testemunhal; 
d. o uso de modelos trajados com uniformes, fardas ou vestimentas características de uma profissão não deverá induzir o Consumidor a erro e será sempre limitado pelas normas éticas da profissão retratada;

e. o uso de sósias depende de autorização da pessoa retratada ou imitada e não deverá induzir a confusão.

Alegando violação tanto ao art. 23 quanto ao art. $27, \S 2^{\circ}$ e $3^{\circ}$, a Representação n. 100/11 ${ }^{70}$, iniciada a partir de denúncia da Unilever contra anúncio da Colgate-Palmolive, é um elucidativo exemplo de aplicação prática do princípio da apresentação verdadeira. Baseando-se em teste sensorial produzido pelo Instituto de Tecnologia de Alimentos, a Unilever, denunciante, contestou afirmação contida em campanha do creme dental Sorriso Fresh Explosion Night de que o uso do produto antes de dormir proporcionaria refrescância durante toda a noite.

A anunciante, em sua defesa, "contrapôs três testes que comprovariam o claim e informa que este - "explosão de refrescância e proteção do hálito que dura por toda a noite" - foi validado pela Anvisa. ${ }^{71}$, A relatora concedeu medida liminar recomendando a sustação da campanha até o seu julgamento. Em seu voto final, reconheceu a validade dos estudos e da frase aprovada pela autoridade sanitária no que concerne à proteção que o produto traz ao hálito, mas considerou não ter ficado comprovada a refrescância destacada na campanha. Por isso, recomendou a alteração do anúncio, e teve o seu voto aprovado pela maioria do Conselho de Ética.

Também concernente ao princípio da apresentação verdadeira, a Representação n. 279/99 foi iniciada contra o refrigerante Sprite a partir de denúncia do "Clube do Fox Paulistinha". Ao promover a bebida, a marca utilizou a imagem de um cão da raça Fox Paulistinha associada à expressão "vira lata":

Recofarma e Lowe Loducca ingressaram com recurso contra decisão de primeira instância, que recomendou alteração do back-light onde a imagem de um cão comprovadamente da raça Fox Paulistinha aparece associada à expressão vira-

\footnotetext{
${ }^{70}$ Casos CONAR - Decisões Junho/2011. Disponível em $<$ http://www.conar.org.br $>$. Acesso em 12 out. 2013.

${ }^{71}$ Casos CONAR - Decisões Junho/2011. Disponível em $<$ http://www.conar.org.br $>$. Acesso em 12 out. 2013
} 
lata. Anunciante e agência ponderam que o anúncio não tem conotação pejorativa, tampouco representou prejuízo para os criadores da raça. Explicam que vira-lata foi empregado apenas como sinônimo de cão. Procuram demonstrar, por fim, que a raça Fox Paulistinha teria surgido do cruzamento de cães originariamente ingleses com cachorros sem raça definida - vira-latas, como são popularmente conhecidos -, vindo a se constituir numa raça acreditada internacionalmente apenas na segunda metade do século XX. Os autores, por sua vez, repisaram seus argumentos de primeira instância, que terminaram acolhidos por unanimidade pelos membros da Câmara Especial de Recursos ${ }^{72}$.

\section{IV.2.3. Medo, Superstição, Violência}

Os artigos 24, 25 e 26 do $\mathrm{CBAP}^{73}$ determinam que a publicidade não deverá apoiar-se e nem explorar o medo, a superstição e a violência. Denise Fabretti explica que "esta modalidade de publicidade abusa da boa fé ou tira proveito das inquietações ante perigos reais ou imaginários do consumidor (medo), ou ainda aproveita-se de sentimento de crendice ou de sentimento religioso baseado no temor ou na ignorância do público (superstição)." ${ }^{, 74} \mathrm{O}$ CDC, inclusive, no artigo $37, \S 2^{075}$, descreve a publicidade "que incite à violência, explore o medo ou a superstição" como uma das modalidades de propaganda abusiva.

\footnotetext{
${ }^{72}$ Casos CONAR - Decisões Maio/2000. Disponível em <http://www.conar.org.br>. Acesso em 14 set. 2013.

${ }^{73}$ Artigo 24. Os anúncios não devem apoiar-se no medo sem que haja motivo socialmente relevante ou razão plausível.
}

Artigo 25. Os anúncios não devem explorar qualquer espécie de superstição.

Artigo 26. Os anúncios não devem conter nada que possa conduzir à violência.

${ }^{74}$ FABRETTI, Denise. Publicidade Abusiva. Disponível em $<\mathrm{http}$ ://acervodigital.espm.br/revista_da_espm/1995/nov/publicidade_abusiva.pdf>. Acesso em 15 set. 2013.

${ }^{75}$ Artigo 37, § 2o. É proibida toda publicidade enganosa ou abusiva.

$\S 2^{\circ} E$ abusiva, dentre outras a publicidade discriminatória de qualquer natureza, a que incite à violência, explore o medo ou a superstição, se aproveite da deficiência de julgamento e experiência da criança, desrespeita valores ambientais, ou que seja capaz de induzir o consumidor a se comportar de forma prejudicial ou perigosa à sua saúde ou segurança. 
Na Representação n. $200 / 99^{76}$, o Conar, a partir de queixas de consumidores, denunciou o Playcenter e a agência Agnelo Pacheco, com base no art. 24 do CBAP. No filme comercial, que promove as "noites de terror do Playcenter", mortos começam a se mover em um necrotério, atraídos por ingressos do parque. Após examinar os argumentos da defesa, $\mathrm{o}$ relator recomendou o arquivamento da representação, considerando o filme "uma debochada e pesada brincadeira, bem ao gosto dos adolescentes" $"$. O seu voto foi acolhido por unanimidade.

Outro caso envolvendo o art. 24 do CBAP é a Representação $n^{\circ}$ $4 / 03^{78}$, de fevereiro de 2003, aberta de ofício pelo Conar contra o serviço de proteção via satélite Car System. No entendimento do diretor executivo do Conar, o anúncio de TV da empresa teria abusado do medo para convencer os consumidores das vantagens do serviço. No filme, aparecem várias cenas de famílias sendo assaltadas em seus carros. A Car System refutou a acusação afirmando que "o anúncio expõe com exatidão o sistema e o funcionamento, evidenciando a sua principal característica, que é a proteção da pessoa"79. A defesa alegou ainda "ter exibido cenas realistas, que não teriam o condão de induzir o consumidor, movido pelo medo, a comprar o produto" ${ }^{\prime 80}$.

Apesar de concordar com o argumento de que o filme apresenta fielmente o produto, o relator chamou a atenção para a utilização de "recursos indigentes de imaginação, o que efetivamente contribui para estimular a neurose de segurança na população" ${ }^{81}$. Para justificar a recomendação pela sustação do filme, afirmou ainda ter "a certeza de que é

\footnotetext{
${ }^{76}$ Casos CONAR - Decisões Outubro/1999. Disponível em $<$ http://www.conar.org.br $>$. Acesso em 02 set. 2013.

${ }^{77}$ Casos CONAR - Decisões Outubro/1999. Disponível em $<$ http://www.conar.org.br $>$. Acesso em 02 set. 2013

${ }^{78}$ Casos CONAR - Decisões Fevereiro/2003. Disponível em $<$ http://www.conar.org.br $>$. Acesso em 11 out. 2013.

${ }^{79}$ Casos CONAR - Decisões Fevereiro/2003. Disponível em $<$ http://www.conar.org.br $>$. Acesso em 11 out. 2013.

${ }^{80}$ Casos CONAR - Decisões Fevereiro/2003. Disponível em $<$ http://www.conar.org.br $>$. Acesso em 11 out. 2013.

${ }^{81}$ Casos CONAR - Decisões Fevereiro/2003. Disponível em $<$ http://www.conar.org.br $>$. Acesso em 11 out. 2013.
} 
possível fazer um comercial para o serviço que reproduza fielmente suas características sem recorrer a esse primarismo nefasto" ${ }^{82}$. O seu voto foi aceito por unanimidade.

\section{IV.2.4. Identificação Publicitária}

Artigo 28. O anúncio deve ser claramente distinguido como tal, seja qual for a sua forma ou meio de veiculação.

Artigo 29. O Anunciante será sempre facilmente identificável, seja pela marca do produto, seja pelo nome do fabricante, fornecedor ou distribuidor, exceção feita ao previsto no parágrafo único do artigo $9^{\circ}$. É recomendado, também, que as Agências se identifiquem nos anúncios impressos veiculados sob sua responsabilidade.

Consoante aos arts. 28 e 29 do CBAP, o CDC, no caput do seu art. $36^{83}$, também prevê a identificação publicitária como um dos princípios basilares do código. O consumerista Leonardo de Medeiros Garcia assim define o princípio: "a publicidade, quando veiculada, tem o dever de ser identificada como tal, de modo fácil e imediato pelo consumidor" ${ }^{84}$ Desta forma, "o anúncio deve ser divulgado e deve apresentar-se como tal, oferecendo ao destinatário a consciência inequívoca de que se encontra diante de uma manifestação publicitária, e com clareza em seu conteúdo ${ }^{85}$.

Como consequência lógica do princípio da identificação publicitária, o caput do art. 29 do $\mathrm{CBAP}^{86}$ veda a chamada propaganda subliminar,

\footnotetext{
${ }^{82}$ Casos CONAR - Decisões Fevereiro/2003. Disponível em $<$ http://www.conar.org.br $>$. Acesso em 11 out. 2013.

${ }^{83}$ Código de Defesa do Consumidor, Art. 36, caput. A publicidade deve ser veiculada de tal forma que o consumidor, fácil e imediatamente, a identifique como tal.

${ }^{84}$ GARCIA, Leonardo de Medeiros. Direito do Consumidor: Código Comentado e Jurisprudência. Niterói: Impetus, 2010, p. 235.

${ }^{85} 5^{\text {a }}$ Câmara Cível - TJ, Apel. . 596.126.037-RS, Rel. Des. Araken de Assis, Porto Alegre, 22 ago. 1996.

${ }^{86}$ CBAP, Art. 29. Este Código não se ocupa da chamada "propaganda subliminar”, por não se tratar de técnica comprovada, jamais detectada de forma juridicamente inconteste. São
} 
sendo esta a que "atinge somente o inconsciente do indivíduo, fazendo com que não perceba que está sendo induzido a comprar"87. Ainda que não a reconheça como modalidade de publicidade, o Código proíbe "quaisquer tentativas destinadas a produzir efeitos 'subliminares' em publicidade ou propaganda".

Questão pertinente e atual referente à identificação publicitária diz respeito à publicação de posts em blogs dedicados à moda e cosméticos. Nos últimos anos, muitos "blogueiros" e "blogueiras" angariaram milhares, ou até milhões, de leitores para os seus blogs de moda e tendências, onde dão dicas sobre o assunto. No entanto, muitas vezes, o que parece ser uma recomendação sincera de um produto, livre de qualquer interesse obscuro, é na verdade um anúncio publicitário disfarçado de post.

Em setembro de 2012, o CONAR julgou pela primeira vez um caso desse tipo. As Representações n. 221/12, 222/12, e 223/12, que tiveram tramitação, parecer e voto simultâneos, questionaram se houve publicidade não identificada como tal na divulgação de produtos cosméticos da Sephora em três blogs distintos. O que chamou a atenção das consumidoras que denunciaram o caso foi a "coincidência de datas e expressões usadas pelas blogueiras na divulgação de produtos cosméticos da Sephora, na indicação do endereço eletrônico da loja e o fato de terem sido ilustradas com imagens de produtos em cujo rótulo há a menção 'not for sale",88.

A defesa de um dos denunciados, o "Blog da Mariah", reconheceu que "a autora aceita os chamados publiposts em sua coluna, mas estes são claramente identificados como tal, não sendo o caso dos denunciados pelos consumidores" 89 . Ao final do processo, o relator decidiu por uma

condenadas, no entanto, quaisquer tentativas destinadas a produzir efeitos "subliminares" em publicidade ou propaganda.

${ }^{87}$ GARCIA, Leonardo de Medeiros. Direito do Consumidor: Código Comentado e Jurisprudência. Niterói: Impetus, 2010, p. 235.

${ }^{88}$ Casos CONAR - Decisões Setembro/2012. Disponível em $<$ http://www.conar.org.br $>$. Acesso em 03 set. 2013.

${ }^{89}$ Casos CONAR - Decisões Setembro/2012. Disponível em $<$ http://www.conar.org.br $>$. Acesso em 03 set. 2013. 
advertência aos três blogs e à anunciante devido "ao desconforto causado a seguidores dos blogs e às normas éticas da identificação publicitária previstas no Código" 90 . Em seu voto, observou ainda que "a ética publicitária aplica-se a todo e qualquer meio de comunicação, incluída a web, que se associou ao Conar e aderiu às normas em vigor por meio da IAB Brasil ${ }^{91}$ e que reúne todos os portais que exploram a publicidade." 92

\section{IV.2.5. Propaganda Comparativa}

Nas palavras de Fernando Gherardini Santos, a publicidade comparativa ocorre "quando a mensagem destaca um produto ressaltando suas características e relação a outros similares de outras marcas" ${ }^{93}$. No mesmo sentido, Marco Antonio Marcondes Pereira define a publicidade comparativa como o "método, ou técnica, de confronto empregado por um anunciante, destinado a enaltecer as qualidades ou preço de seus produtos ou serviços em relação a produtos ou serviços de um ou mais concorrentes, explícita ou implicitamente ${ }^{94 \%}$.

No âmbito da autorregulação, a publicidade comparativa é permitida, mas desde que respeitadas as regras do art. 32 do CBAP:

Artigo 32. Tendo em vista as modernas tendências mundiais - e atendidas as normas pertinentes do Código da Propriedade Industrial (Lei $\mathrm{n}^{\circ} 5.772$, de 21 de dezembro de 1971) - a publicidade comparativa será aceita, contanto que respeite os seguintes princípios e limites:

a. seu objetivo maior seja o esclarecimento, se não mesmo a defesa do consumidor;

\footnotetext{
${ }^{90}$ Casos CONAR - Decisões Setembro/2012. Disponível em $<$ http://www.conar.org.br $>$. Acesso em 03 set. 2013.

91 Interactive Advertising Bureau Brasil

${ }^{92}$ Casos CONAR - Decisões Setembro/2012. Disponível em $<$ http://www.conar.org.br $>$. Acesso em 03 set. 2013.

${ }^{93}$ SANTOS, Fernando Gherardini. Direito do Marketing: uma abordagem jurídica do marketing empresarial. São Paulo: Ed. Revista dos Tribunais, 2000, p. 32.

${ }_{94}$ PEREIRA, Marco Antonio Marcondes. Concorrência desleal por meio da publicidade. São

Paulo: Juarez de Oliveira, 2001, p. 89.
} 
b. tenha por princípio básico a objetividade na comparação, posto que dados subjetivos, de fundo psicológico ou emocional não constituem uma base válida de comparação perante o Consumidor;

c. a comparação alegada ou realizada seja passível de comprovação;

d. em se tratando de bens de consumo a comparação seja feita com modelos fabricados no mesmo ano, sendo condenável o confronto entre produtos de épocas diferentes, a menos que se trate de referência para demonstrar evolução, o que, nesse caso, deve ser caracterizado;

e. não se estabeleça confusão entre produtos e marcas concorrentes;

f. não se caracterize concorrência desleal, denegrimento à imagem do produto ou à marca de outra empresa;

g. não se utilize injustificadamente a imagem corporativa ou o prestígio de terceiros;

h. quando se fizer uma comparação entre produtos cujo preço não é de igual nível, tal circunstância deve ser claramente indicada pelo anúncio.

$\mathrm{O}$ art. 32, portanto, admite a publicidade comparativa quando esta não for uma publicidade enganosa. No dizer de Marco Antonio Marcondes Pereira, "as limitações ou preceitos que devem nortear a publicidade comparativa, estabelecidas no referido diploma autodisciplinar, na realidade, se harmonizam com os princípios básicos da publicidade"95 - em especial com os princípios da veracidade e da identificação publicitária.

A grande maioria das denúncias referentes à propaganda comparativa que chegam ao CONAR dizem respeito à letra "f" do art. 32, ou seja, ao denegrimento de imagem. A Representação n. 127/05 ${ }^{96}$, de Agosto de 2005, é um ótimo exemplo disto. A cervejaria Primo Schincariol acusou a Ambev de denegrir a imagem do seu produto Nova Schin através de anúncio de TV da Antarctica. Na peça publicitária, após provar uma cerveja "nova", um jovem a rejeita, dizendo "credo!". Em sua defesa, anunciante e agência alegaram que "em momento algum é citado o nome do produto da concorrente e que a peça apenas faz uso do bom humor"97. O relator, por sua vez, "julgou que a publicidade comparativa está evidente, uma vez que a peça da Antarctica remete específica e

\footnotetext{
${ }^{95}$ PEREIRA, Marco Antonio Marcondes. Concorrência desleal por meio da publicidade. São Paulo: Juarez de Oliveira, 2001, p. 105.

${ }^{96}$ Casos CONAR - Decisões Agosto/2005. Disponível em $<\mathrm{http}: / /$ www.conar.org.br $>$. Acesso em 12 out. 2013.

${ }^{97}$ Casos CONAR - Decisões Agosto/2005. Disponível em $<$ http://www.conar.org.br $>$. Acesso em 12 out. 2013.
} 


\title{
intencionalmente ao comercial da Schincariol, configurando desrespeito
} ao Código" $"$ ".

Outro caso ilustrativo envolvendo o denegrimento de imagem é a Representação n. 59/0599:

O IG protesta contra comercial veiculado em TV do concorrente Oi Internet, queixando-se que a utilização na peça de um cachorro da raça terrier, idêntico ao símbolo do IG, em situação vexatória, caracterizaria comparação de forma não objetiva entre as empresas. Houve concessão de liminar sustando o anúncio. Em sua defesa, a Oi Internet negou a hipótese de propaganda comparativa, alegando que o emprego do cachorro não comete nenhuma infração, constituindo apenas uma forma bem-humorada de comunicar o lançamento da empresa. Acrescentou que o comercial não será mais veiculado. $\mathrm{O}$ relator, em seu parecer, considerou que a propaganda comparativa na peça é inegável e que a mensagem veiculada denigre o concorrente IG. Seu voto pela sustação foi aceito por unanimidade.

\section{Marcas de cerveja são pródigas na criação e veiculação de peças}

publicitárias comparativas irregulares. Neste sentido, é cabível observar a

Representação n. 170/0 $7^{100}$ :

\begin{abstract}
A Ambev e sua agência, Africa, iniciaram representações no Conar visando o comercial de TV da cerveja Sol, da Kaiser. As denúncias entendem que a peça é denegritória ao intitular um ponto-de-venda como "Bar do Zeca", claramente pretendendo fazer referência ao cantor Zeca Pagodinho, garoto-propaganda da cerveja Brahma, da Ambev. Indica que a intenção de denigrir fica evidente por mostrar o "Bar do Zeca" como um lugar triste, vazio e decadente, onde se pede "a de sempre", que muda para um lugar alegre e festivo com a chegada da cerveja Sol. A defesa concorda que houve a intenção de provocar uma troca de produto ao mencionar "a de sempre", incentivando o consumidor a trocar qualquer outra marca pela Sol, mas que não há nenhum elemento de denegrimento ou ofensa a Ambev ou a Brahma. Argumenta que o "Zeca" no nome do bar é apenas o uso de um apelido comum, não sendo propriedade de ninguém. Ao considerar a questão, o relator refletiu que a peça usa elementos que lembram ícones dos anúncios da concorrente e que ao nomear o bar do comercial como "do Zeca", carrega para o entendimento de que não é qualquer "Zeca". Por isso, recomendou a alteração do anúncio, aceita por maioria de votos.
\end{abstract}

\section{IV.2.6. Segurança e Acidentes}

\footnotetext{
${ }^{98}$ Casos CONAR - Decisões Agosto/2005. Disponível em <http://www.conar.org.br>. Acesso em 12 out. 2013.

${ }^{99}$ Casos CONAR - Decisões Maio/2005. Disponível em $<$ http://www.conar.org.br $>$. Acesso em 12 out. 2013.

${ }^{100}$ Casos CONAR - Decisões Maio/2005. Disponível em $<$ http://www.conar.org.br $>$. Acesso em 12 out. 2013.
} 
$\mathrm{O}$ art. 33 do $\mathrm{CBAP}^{101}$ tem por objetivo vedar qualquer publicidade que induza o consumidor a se comportar de maneira negligente ou imprudente em relação à sua segurança ou saúde.

Os casos mais frequentes de violação ao art. 33 dizem respeito aos anúncios de automóveis. A Representação n. $128 / 10^{102}$, por exemplo, foi instaurada a partir de queixas de consumidores ao comercial veiculado pela Ford para divulgar o modelo Fiesta 2011. No filme, manobristas “desrespeitam a ordem de chegada dos veículos no estabelecimento, dando preferência aos motoristas do modelo promovido, em virtude de seus atributos, como é explicitado pela locução." ${ }^{103} \mathrm{Na}$ visão dos consumidores queixosos, o anúncio viola $\mathrm{o}$ art. 33 na medida em que apresenta comportamento irregular e desmerecedor da categoria de manobristas, além de apresentá-los dirigindo sem o cinto de segurança.

A defesa alegou que "o mundo da publicidade é diferente e deve ser desvinculado do mundo real, uma vez que pode valer-se de linguagem e recursos próprios, visando destacar aspectos do produto." E afirmou ainda que "como o consumidor sabe diferenciar essas duas esferas, a publicidade não tem como influenciar o comportamento dos manobristas, nem dos motoristas, no que diz respeito ao uso do cinto de segurança." ${ }^{104}$ Em seu voto, o relator não viu problema na abordagem da questão dos manobristas, dado o seu evidente apelo lúdico, mas considerou inadequada a falta do uso do cinto de segurança. Desta forma, decidiu pela alteração do comercial,

\footnotetext{
${ }^{101}$ Artigo 33. Este Código condena os anúncios que:

a. manifestem descaso pela segurança, sobretudo quando neles figurarem jovens e crianças ou quando a estes for endereçada a mensagem;

b. estimulem o uso perigoso do produto oferecido;

c. deixem de mencionar cuidados especiais para a prevenção de acidentes, quando tais cuidados forem essenciais ao uso do produto;

d. deixem de mencionar a responsabilidade de terceiros, quando tal menção for essencial;

e. deixem de especificar cuidados especiais no tocante ao uso do produto por crianças, velhos $e$ pessoas doentes, caso tais cuidados sejam essenciais.

${ }^{102}$ Casos CONAR - Decisões Julho/2010. Disponível em $<$ http://www.conar.org.br $>$. Acesso em 11 out. 2013.

${ }^{103}$ Casos CONAR - Decisões Julho/2010. Disponível em $<$ http://www.conar.org.br $>$. Acesso em 11 out. 2013.

${ }^{104}$ Casos CONAR - Decisões Julho/2010. Disponível em <http://www.conar.org.br>. Acesso em 11 out. 2013.
} 
para que o anunciante retratasse o condutor cumprindo as leis de trânsito, e teve o seu voto acatado pela unanimidade do Conselho de Ética.

A Representação n. $245 / 11^{105}$, por sua vez, questionou um catálogo da loja Fnac para o Dia das Crianças ilustrado por "fotos de um bebê que pintou o próprio rosto, inclusive a boca, com canetas hidrográficas, e outro que aparece mordendo um pincel ainda sujo de tinta" ${ }^{106}$. Para os consumidores queixosos, configurou-se situação inadequada e que implica risco para os modelos, com base no art. 33. Em sua defesa, o anunciante alegou que a campanha visa apenas mostrar a espontaneidade das crianças, e que o anúncio é dirigido a adultos. Em voto aceito por unanimidade, a relatora propôs a alteração do catálogo, para que o anunciante não use material fotográfico que possa pôr em risco a segurança das crianças.

\section{IV.2.7. Poluição e Ecologia}

$\mathrm{O}$ art. 36 do CBAP proíbe qualquer espécie de publicidade que desrespeite, de alguma forma, o meio ambiente:

Artigo 36. Não podendo a publicidade ficar alheia às atuais e prementes preocupações de toda a Humanidade com os problemas relacionados com qualidade de vida e a proteção do meio ambiente, serão vigorosamente combatidos os anúncios que direta ou indiretamente estimulem:

a. a poluição do ar, das águas, das matas e dos demais recursos naturais;

b. a poluição do ambiente urbano;

c. a depredação da fauna, da flora e dos demais recursos naturais;

d. a poluição visual dos campos e da cidade;

e. a poluição sonora;

f. o desperdício de recursos naturais.

\footnotetext{
${ }^{105}$ Casos CONAR - Decisões Novembro/2011. Disponível em $<$ http://www.conar.org.br>. Acesso em 11 out. 2013.

${ }^{106}$ Casos CONAR - Decisões Novembro/2011. Disponível em $<$ http://www.conar.org.br>. Acesso em 11 out. 2013 .
} 
A Representação n. 020, de $1998^{107}$, foi iniciada de ofício pelo CONAR contra anúncio do Guaraná Brahma para TV. A peça "Guaraná Brahma, macaco no zoológico" mostra uma família em visita ao jardim zoológico. "Diante de uma jaula, o pai bebe uma lata de Guaraná Brahma e provoca o macaco, mesmo diante dos protestos do filho. Quando termina, entrega a lata ao macaco." ${ }^{108} \mathrm{O}$ animal, depois de conferir se a latinha está mesmo vazia, joga o objeto de volta na cabeça do pai.

Com base no art. 33, letra "a", o Conar abriu processo por "entender que o comercial poderia estimular os visitantes a alimentar os animais em suas jaulas, desmerecendo campanhas educativas que administradores de zoológicos desenvolvem no mundo todo"109. Em sua defesa, a agência responsável alegou que o filme tinha um claro propósito cômico e que tratava-se de situação fíctícia, na medida em que nos zoológicos não haveria fácil acesso aos animais. Apesar de reconhecer o intuito bem humorado do comercial, o relator do processo em primeira instância recomendou a sustação da peça, e teve o seu parecer aceito por maioria dos votos. Interposto o recurso ordinário, o relator do recurso entendeu que, além do art. 33, a, o comercial infringiu o art. $6^{\circ}$ do $\mathrm{CBAP}^{110}$, pelo seu "forte caráter deseducativo". Desta forma, recomendou manter a sustação da peça e teve o seu entendimento acompanhado pela maioria dos conselheiros:

Alegar o espírito bem-humorado e criativo do comercial não justifica os malefícios que pode causar. Nós todos conhecemos a força da TV e sabemos o

\footnotetext{
${ }^{107}$ Casos CONAR - Decisões Dezembro/1998. Disponível em $<$ http://www.conar.org.br $>$. Acesso em 03 set. 2013.

${ }^{108}$ Casos CONAR - Decisões Dezembro/1998. Disponível em $<$ http://www.conar.org.br $>$. Acesso em 03 set. 2013.

${ }^{109}$ Casos CONAR - Decisões Dezembro/1998. Disponível em $<$ http://www.conar.org.br $>$. Acesso em 03 set. 2013.
} ${ }^{110}$ Artigo $6^{\circ}$. Toda publicidade deve estar em consonância com os objetivos do desenvolvimento
econômico, da educação e da cultura nacionais. 
quanto ela pode ser prejudicial à educação, ainda que muitas vezes sem a menor intenção, como aliás acreditamos seja o caso em questão ${ }^{111}$.

Outro caso envolvendo o art. 36, entre outros princípios, diz respeito à Representação n. 102/10:

Anúncio para TV da Vodka Absolut mostra balões de festas juninas sendo soltos. A imagem atraiu reclamação de consumidor carioca, que lembrou ser ilegal tal prática, de acordo com a Lei $n^{\circ}$ 9605/98. Em sua defesa, a anunciante alegou que as imagens envolvendo os balões são apenas "licença poética" para a formação de palavras. Não considera que o filme possa estimular a soltura de balões.

A relatora de primeira instância propôs a alteração, de forma a eliminar do filme as cenas objeto da representação. "O filme conta com uma criação ousada e diferente, mas não está em conformidade com o artigo $1^{\circ}$ do Código e também com os artigos 21 e 36 ", escreveu ela em seu voto. $\mathrm{O}$ artigo $1^{\circ}$ diz que toda peça publicitária deve se conformar às leis vigentes; o artigo 21 , que "os anúncios não devem conter nada que possa induzir a atividades criminosas ou ilegais - ou que pareça favorecer, enaltecer ou estimular tais atividades", e o artigo 36, que serão combatidos os anúncios que direta ou indiretamente estimulem a poluição, a depredação da fauna e da flora e o desperdício de recursos naturais.

Além disso, a relatora ponderou que o filme pode atrair atenção de crianças e adolescentes, o que é vedado pelo Anexo A do Código Éticopublicitário. Seu voto foi aceito por unanimidade. Houve recurso por parte do anunciante, mas a decisão inicial foi confirmada por unanimidade pela câmara revisora, seguindo parecer do relator. ${ }^{12}$

\section{IV.2.8. Crianças e Jovens}

No início de 2013, a sessão 11 do CBAP, que trata da publicidade direcionada ao público infanto-juvenil, foi totalmente reformulada, com a instituição de regras severas para ações de merchandising direcionadas à crianças $^{113}$. No entanto, esta não foi a primeira vez que a sessão 11 do CBAP foi modificada.

\footnotetext{
${ }^{111}$ Casos CONAR - Decisões Dezembro/1998. Disponível em $<$ http://www.conar.org.br>. Acesso em 03 set. 2013.

${ }^{112}$ Casos CONAR - Decisões Julho/2011. Disponível em <http://www.conar.org.br>. Acesso em 03 set. 2013.

${ }^{113}$ Conar defende autorregulamentação na publicidade infantil. Disponível em < http://propmark.uol.com.br/mercado/45688:conar-defende-autorregulamentacao-na-publicidadeinfantil>. Acesso em 10 out. 2013.
} 
Antes disso, a publicidade infantil já havia sido restringida de forma mais significativa em 2006. Na ocasião, foi proibido o emprego de crianças e adolescentes como modelos para vocalizar apelo direto ou sugestão de uso ou consumo, ou seja, passou a ser vetado o uso de menores para sugerir ao público a noção de que determinado produto ou serviço proporcione superioridade. Além disso, ficou proibido o emprego de mensagens que, por meio dos menores, provoquem situações de constrangimento aos pais ou responsáveis para coagi-los ao consumo ${ }^{114}$.

\section{Após todas essas modificações, assim ficou a redação do art. 37:}

Artigo 37 - Os esforços de pais, educadores, autoridades e da comunidade devem encontrar na publicidade fator coadjuvante na formação de cidadãos responsáveis e consumidores conscientes. Diante de tal perspectiva, nenhum anúncio dirigirá apelo imperativo de consumo diretamente à criança. E mais:

I - Os anúncios deverão refletir cuidados especiais em relação à segurança e às boas maneiras e, ainda, abster-se de: a) desmerecer valores sociais positivos, tais como, dentre outros, amizade, urbanidade, honestidade, justiça, generosidade e respeito a pessoas, animais e ao meio ambiente; b) provocar deliberadamente qualquer tipo de discriminação, em particular daqueles que, por algum motivo, não sejam consumidores do produto; c) associar crianças e adolescentes a situações incompatíveis com sua condição, sejam elas ilegais, perigosas ou socialmente condenáveis; d) impor a noção de que o consumo do produto proporcione superioridade ou, na sua falta, a inferioridade; e) provocar situações de constrangimento aos pais ou responsáveis, ou molestar terceiros, com o propósito de impingir o consumo; f) empregar crianças e adolescentes como modelos para vocalizar apelo direto, recomendação ou sugestão de uso ou consumo, admitida, entretanto, a participação deles nas demonstrações pertinentes de serviço ou produto; g) utilizar formato jornalístico, a fim de evitar que anúncio seja confundido com notícia; h) apregoar que produto destinado ao consumo por crianças e adolescentes contenha características peculiares que, na verdade, são encontradas em todos os similares; i) utilizar situações de pressão psicológica ou violência que sejam capazes de infundir medo.

II - Quando os produtos forem destinados ao consumo por crianças e adolescentes, seus anúncios deverão: a) procurar contribuir para o desenvolvimento positivo das relações entre pais e filhos, alunos e professores, e demais relacionamentos que envolvam o público-alvo; b) respeitar a dignidade, a ingenuidade, a credulidade, a inexperiência e o sentimento de lealdade do público-alvo; c) dar atenção especial às características psicológicas do públicoalvo, presumida sua menor capacidade de discernimento; d) obedecer a cuidados tais que evitem eventuais distorções psicológicas nos modelos publicitários e no público-alvo; e) abster-se de estimular comportamentos socialmente condenáveis.

Parágrafo $1^{\circ}$. Crianças e adolescentes não deverão figurar como modelos publicitários em anúncio que promova o consumo de quaisquer bens e serviços incompatíveis com sua condição, tais como armas de fogo, bebidas alcoólicas, cigarros, fogos de artifício e loterias, e todos os demais igualmente afetados por restrição legal.

\footnotetext{
${ }^{114}$ Conar defende autorregulamentação na publicidade infantil. Disponível em < http://propmark.uol.com.br/mercado/45688:conar-defende-autorregulamentacao-na-publicidadeinfantil>. Acesso em 10 out. 2013.
} 
Parágrafo $2^{\circ}$. O planejamento de mídia dos anúncios de produtos de que trata o inciso II levará em conta que crianças e adolescentes têm sua atenção especialmente despertada para eles. Assim, tais anúncios refletirão as restrições técnica e eticamente recomendáveis, e adotar-se-á a interpretação mais restritiva para todas as normas aqui dispostas.

$\mathrm{O}$ art. 37 do CBAP está em perfeita sintonia com as normas e princípios do Estatuto da Criança e do Adolescente (ECA) e dos dispositivos referentes à publicidade direcionada ao público infantil previstos no CDC. Dentre esses, é possível destacar os arts. $71^{115}, 76^{116} \mathrm{e}$ $79^{117}$ do ECA, e art. 39, IV do $\mathrm{CDC}^{118}$. Sobre o art. 71 do ECA, Isabela Vieira Machado Henriques leciona:

Ciente das dificuldades reais relativamente ao que é apresentado às crianças e aos adolescentes brasileiros pela mídia de maneira geral, o legislador, no art. 71 do Estatuto da Criança e do Adolescente, estipula o direito da criança e do adolescente à informação, cultura, lazer, esportes, diversões, espetáculos, produtos e serviços que respeitem a sua condição peculiar de pessoas em desenvolvimento. Assim, tudo o que for oferecido às crianças e aos adolescentes, inclusive por meio da publicidade, conforme lei, deve ser compatível e adequado com sua faixa etária, respeitando-se as diversas fases do desenvolvimento físico e mental dessas pessoas em formação ${ }^{119}$.

\section{Também quanto aos princípios do ECA, é importante ressaltar o}

direito ao respeito, previsto no art. 17, e que consiste, nos termos do artigo, na "inviolabilidade da integridade física, psíquica e moral da criança e do adolescente, abrangendo a preservação da imagem, da identidade, da autonomia, dos valores, ideias e crenças, dos espaços e objetos pessoais." O direito ao respeito é corolário do princípio da proteção integral, que, por sua

\footnotetext{
${ }^{115}$ Art. 71. A criança e o adolescente têm direito a informação, cultura, lazer, esportes, diversões, espetáculos e produtos e serviços que respeitem sua condição peculiar de pessoa em desenvolvimento.

${ }^{116}$ Art. 76. As emissoras de rádio e televisão somente exibirão, no horário recomendado para o público infanto juvenil, programas com finalidades educativas, artísticas, culturais e informativas. ${ }^{117}$ Art. 79. As revistas e publicações destinadas ao público infanto-juvenil não poderão conter ilustrações, fotografias, legendas, crônicas ou anúncios de bebidas alcoólicas, tabaco, armas e munições, e deverão respeitar os valores éticos e sociais da pessoa e da família.

${ }^{118}$ CDC, art. 39, IV. É vedado ao fornecedor de produtos ou serviços, dentre outras práticas abusivas:

IV - prevalecer-se da fraqueza ou ignorância do consumidor, tendo em vista sua idade, saúde, conhecimento ou condição social, para impingir-lhe seus produtos ou serviços.

${ }^{119}$ HENRIQUES, Isabela Vieira Machado. Publicidade abusiva dirigida à criança. Curitiba, Editora Jaruá, 2006, pp. 164-165.
} 
vez, pode ser entendido, nas palavras de Antonio Carlos Gomes da Costa, da seguinte maneira:

Esta doutrina afirma o valor intrínseco da criança como ser humano; a necessidade de especial respeito à sua condição de pessoa em desenvolvimento; o valor prospectivo da infância e da juventude, como portadora da continuidade do seu povo e da espécie e o reconhecimento da sua vulnerabilidade o que torna as crianças e adolescentes merecedores de proteção integral por parte da família, da sociedade e do Estado, o qual deverá atuar através de políticas específicas para promoção e defesa de seus direitos ${ }^{120}$.

Desta forma, "no momento em que nos deparamos com uma publicidade voltada para o público infantil em que afirma que ter tal brinquedo ou tal roupa irá fazer com que ele se destaque e seja o herói entre os seus amigos, e ele não consegue obter aquele objeto de consumo, essa sua integridade acaba de ser violada" ${ }^{21}$. Este é um exemplo claro de publicidade direcionada ao público infantil que o CBAP visa combater.

Alegando desrespeito ao art. 37 do CBAP, a Representação n. 094/10 foi iniciada a partir de queixas de consumidores ao anúncio de Sustagen Kids veiculado na TV. A denúncia afirmou que a mensagem apresenta exemplo deseducativo de criança rejeitando alimentos vegetais, "o que poderia transmitir a ideia de que é possível substituir tais alimentos pelo produto anunciado, além de induzir à percepção de desmerecimento da alimentação natural"122. A mensagem "um copo de leite com Sustagen Kids oferece $100 \%$ do ferro, zinco e vitamina C que o seu filho precisa", também foi questionada, na medida em que "contradiz que contradiz a informação da locução de que o produto é um "complemento" da alimentação"123.

\footnotetext{
120 COSTA, Antonio Carlos Gomes da. Natureza e implantação do novo direito da criança e do adolescente. In: PEREIRA, Tânia da Silva (Coord.). Estatuto da Criança e do Adolescente: Lei 8.069/90: estudos sócio-jurídicos. Rio de Janeiro: Renovar, 1992, p. 19.

121 VILAS-BÔAS, Renata Malta. Publicidade direcionada ao público infantil: violência contra a criança e contra a sua família. Disponível em $<\mathrm{http}$ ://www.ambitojuridico.com.br/site/index.php?n_link=revista_artigos_leitura\&artigo_id=10551 . Acesso em 12 set. 2013.

${ }^{122}$ Casos CONAR - Decisões Dezembro/2010. Disponível em $<$ http://www.conar.org.br $>$. Acesso em 08 set. 2013.

${ }^{123}$ Casos CONAR - Decisões Dezembro/2010. Disponível em $<$ http://www.conar.org.br $>$. Acesso em 08 set. 2013.
} 
O anunciante, Mead Johnson do Brasil, argumentou que o filme não visa desmerecer a importância da alimentação natural, porque mostra uma mãe que insiste em oferecer vegetais ao filho e, ao final, serve uma fruta. A defesa também reiterou o que é dito textualmente no comercial - que o produto serve para complementar a alimentação natural. Em primeira e segunda instância, o Conselho de Ética e a Câmara Especial de Recursos decidiram pela recomendação de alteração do anúncio, "no sentido de eliminar a apresentação do consumo do produto frente à recusa de alimentos naturais" $" 124$.

Também a partir de queixas de consumidores, a Representação n. $274 / 06^{125}$ foi iniciada frente a comercial de TV do produto Havaianas Kids:

\begin{abstract}
Na peça, um grupo de meninas brinca na praia e uma delas chega calçando apenas um pé do chinelo. As outras começam a rir, quando o ator Kaiky Brito chega com o pé de chinelo perdido e o calça na menina, surpreendendo todo o grupo. Quando o ator se vira para ir embora, as outras meninas jogam seus chinelos na direção dele, esperando tratamento igual. ${ }^{126}$
\end{abstract}

A denúncia alegou que o comercial é inadequado e deseducativo, na medida em que apela à sensualidade em cenas protagonizadas por crianças e demonstra um comportamento desleal de uma criança em relação às outras. A defesa refutou os dois argumentos, afirmando que o comercial apresenta uma situação que remete a um conto de fadas no imaginário das meninas, "onde o ator seria o príncipe encantado levando o calçado perdido para a princesa"127. A relatora concordou com o argumento da defesa e a representação acabou sendo arquivada por unanimidade de votos.

\title{
III.2.9. Direito Autoral e Plágio
}

\footnotetext{
${ }^{124}$ Casos CONAR - Decisões Dezembro/2010. Disponível em $<$ http://www.conar.org.br $>$. Acesso em 08 set. 2013.

${ }^{125}$ Casos CONAR - Decisões Novembro/2006. Disponível em $<\mathrm{http}$ ://www.conar.org.br>. Acesso em 10 set. 2013.

${ }^{126}$ Casos CONAR - Decisões Novembro/2006. Disponível em $<$ http://www.conar.org.br $>$. Acesso em 10 set. 2013.

${ }^{127}$ Casos CONAR - Decisões Novembro/2006. Disponível em $<$ http://www.conar.org.br>. Acesso em 10 set. 2013.
} 
A última sessão do capítulo de princípios gerais do CBAP trata das questões relativas ao direito autoral e plágio na publicidade. Na medida em que o assunto será abordado com a devida atenção no próximo capítulo deste trabalho, proceder-se-á à análise de casos julgados pelo CONAR.

Artigo 38. Em toda a atividade publicitária serão respeitados os direitos autorais nela envolvidos, inclusive os dos intérpretes e os de reprodução.

Artigo 39. O anúncio não utilizará música de fundo, "vinhetas", ou trechos de composições de autores nacionais ou estrangeiros sem o devido respeito aos respectivos direitos autorais, a não ser no caso de músicas que sejam ou se tenham tornado de domínio público, de acordo com a legislação específica, respeitados os direitos de gravação.

Artigo 40. É condenado o uso desrespeitoso da música folclórica, dos folguedos e temas populares que constituem parte integrante do patrimônio cultural do país.

Artigo 41. Este Código protege a criatividade e a originalidade e condena o anúncio que tenha por base o plágio ou imitação, ressalvados os casos em que a imitação é comprovadamente um deliberado e evidente artifício criativo.

Artigo 42. Será igualmente condenado o anúncio que configure uma confusão proposital com qualquer peça de criação anterior.

Artigo 43. O anúncio não poderá infringir as marcas, apelos, conceitos e direitos de terceiros, mesmo aqueles empregados fora do país, reconhecidamente relacionados ou associados a outro Anunciante.

Parágrafo único. Este Código condena a publicidade que faça uso do símbolo oficial e do nome do Conselho Nacional de Auto-Regulamentação Publicitária Conar, exceto em anúncios da própria entidade.

A Representação n. $233 / 11^{128}$ foi aberta a partir de reclamação da Net e de sua agência Talent no sentido de que o slogan de campanha da Nextel - "Seu mundo agora" - induziria o consumidor à confusão. Na denúncia, a Net alegou que utiliza desde 2005 o slogan "Net. O mundo é dos nets", e que em 2011 este foi alterado para "Net. Para os nets é agora." Em sua defesa, a Nextel disse "considerar os slogans suficientemente

\footnotetext{
${ }^{128}$ Casos CONAR - Decisões Novembro/2011. Disponível em $<$ http://www.conar.org.br $>$. Acesso
} em 12 out. 2013. 
distintos para evitar confusões ou questionamento de direitos autorais, inclusive pelo fato de as empresas não atuarem no mesmo segmento" ${ }^{129}$. A relatora votou pelo arquivamento da representação, e teve o seu entendimento acolhido por unanimidade. $\mathrm{Na}$ mesma linha da argumentação da defesa, a relatora considerou que "as assinaturas envolvidas nessa representação são distintas e traduzem conceitos diferentes, sendo precedidas pela identidade dos anunciantes, o que afastaria a possibilidade de confusão" ${ }^{130}$ E observou ainda não parecer ser cabível "que se extraia expressões utilizadas nessas assinaturas para se exigir que recaia sobre elas direitos de exclusividade, quer seu uso seja concomitante ou não." 131

Outro caso envolvendo direitos autorais e plágio diz respeito à Representação n. 147/03, de Julho de 2003. Com fulcro nos arts. 38, 41, 42 e 43, a agência McCann-Erickson denunciou campanha publicitária da goma de mascar Happydent. Em filme para a TV e anúncio em revista, a campanha "mostra partes do corpo de uma mulher associando-as ao custo do que, se presume, seja aplicação de silicone e outros recursos da cirurgia plástica contemporânea"132. A McCann-Erickson considerou as peças da Happydent plágio da sua campanha mundial "Não tem preço", criada para a MasterCard.

Em sua defesa, a anunciante Perfetti Van Melle alegou que a campanha foi inspirada "num corriqueiro e comum ambiente ideológico da comparação dos valores sociais mercadológicos para demonstrar o fácil acesso a um deles"133. E ainda argumentou que faltaria novidade aos anúncios da MasterCard, e que por esta razão, a empresa e a agência não poderiam reivindicar exclusividade sobre o conceito da campanha "Não

\footnotetext{
${ }^{129}$ Casos CONAR - Decisões Novembro/2011. Disponível em $<$ http://www.conar.org.br $>$. Acesso em 12 out. 2013.

${ }^{130}$ Casos CONAR - Decisões Novembro/2011. Disponível em $<$ http://www.conar.org.br $>$. Acesso em 12 out. 2013.

${ }^{131}$ Casos CONAR - Decisões Novembro/2011. Disponível em $<\mathrm{http}$ ://www.conar.org.br>. Acesso em 12 out. 2013.

${ }^{132}$ Casos CONAR - Decisões Julho/2003. Disponível em $<$ http://www.conar.org.br>. Acesso em 13 out. 2013.

${ }^{133}$ Casos CONAR - Decisões Julho/2003. Disponível em $<$ http://www.conar.org.br>. Acesso em 13 out. 2013.
} 
tem preço". Por sua vez, o relator reconheceu a grande semelhança entre as campanhas e considerou que o anunciante aproveitou-se indevidamente da criatividade de outrem. Neste sentido, votou pela sustação da campanha e foi acompanhado pela unanimidade dos conselheiros. 


\section{Publicidade, Concorrência Desleal e Direitos Autorais}

\section{V.1. Publicidade e a concorrência desleal}

É correto dizer que o sistema de autorregulamentação publicitária brasileiro, desde a sua estruturação há mais de trinta anos, tem como finalidade precípua combater as práticas de concorrência desleal entre os anunciantes e as próprias agências de publicidade. O que se busca é impedir a subtração ilícita da clientela e garantir que os players do mercado atuem respeitando as regras do jogo ${ }^{134}$ - nas palavras de Hermano Duval, "competindo lealmente com o indispensável fair play"135. Para Marco Antonio Marcondes Pereira: "o sistema privado de controle da publicidade sustenta-se na ideia da livre concorrência; e, a partir daí, de que os envolvidos nessa atividade possam eles próprios instituírem normas que possam regulamentá-la e inibir os abusos" ${ }^{\prime 136}$. O art. $4^{0}$ do preâmbulo do CBAP expressa isto de forma clara: "Todo anúncio deve respeitar os princípios de leal concorrência geralmente aceitos no mundo dos negócios".

O art. 10 bis da Convenção da União de Paris, da qual o Brasil é signatário, apresenta o seguinte conceito para a concorrência desleal: "Constitui ato de concorrência desleal qualquer ato de concorrência contrário aos usos honestos em matéria industrial e comercial". Não existe consenso na doutrina quanto a uma definição para a concorrência desleal, mas é possível dizer que "é uma espécie de competição que não deve ser feita, por ser conduzida, realizada, através de expedientes escusos, métodos

\footnotetext{
${ }^{134}$ DURIGAN, Paulo Luiz. Publicidade comparativa: informação persuasiva e concorrência. Curitiba, 2007, 268 f. Dissertação (Mestrado em Direito). Faculdades Integradas Curitiba. Disponível em $<$ http://www.apriori.com.br/artigos/publicidadecomparativa.pdf $>$. Acesso em 10 out. 2013.

${ }^{135}$ DUVAL, Hermano. Concorrência desleal. São Paulo: Saraiva, 1976, p. 136.

${ }^{136}$ PEREIRA, Marco Antonio Marcondes. Concorrência desleal por meio da publicidade. São Paulo: Juarez de Oliveira, 2001, p. 65.
} 
incorretos, danosos, que visam modificar a fiel e sadia relação concorrencial"137.

No ordenamento jurídico interno, a concorrência desleal encontra-se prevista na Lei n. 9.279/96, que regula a propriedade industrial. $\mathrm{O}$ art. $2^{\circ}, \mathrm{V}$, da LPI $^{138}$, como também é conhecida a Lei n. 9.279/96, estabelece a repressão à concorrência desleal como um princípio, enquanto o art. 195 considera crime a prática de tais atos. E dentre as condutas que configuram crime de concorrência desleal, as seguintes dizem respeito à publicidade:

\footnotetext{
Art. 195. Comete crime de concorrência desleal quem:

I - publica, por qualquer meio, falsa afirmação, em detrimento de concorrente, com o fim de obter vantagem;

II - presta ou divulga, acerca de concorrente, falsa informação, com o fim de obter vantagem;

IV - usa expressão ou sinal de propaganda alheios, ou os imita, de modo a criar confusão entre os produtos ou estabelecimentos;

$\mathrm{V}$ - usa, indevidamente, nome comercial, título de estabelecimento ou insígnia alheios ou vende, expõe ou oferece à venda ou tem em estoque produto com essas referências;

VI - substitui, pelo seu próprio nome ou razão social, em produto de outrem, o nome ou razão social deste, sem o seu consentimento;

VII - atribui-se, como meio de propaganda, recompensa ou distinção que não obteve;
}

Através da leitura do CBAP e do art. 195 da Lei 9.279/96, não resta dúvida de que a publicidade deve obediência aos princípios que regem a concorrência leal. Em síntese, como explica Marco Antonio Marcondes Pereira, a deslealdade por meio da publicidade se manifesta através de três formas: da publicidade comparativa irregular, da publicidade denigratória, e da publicidade confusória ${ }^{139}$.

Apesar de a publicidade comparativa já ter sido objeto de análise no ponto 4.2.7, são cabíveis algumas considerações adicionais, principalmente

\footnotetext{
${ }^{137}$ GOMES, Franklin. A (Des)necessidade de existência de patente. Disponível em $<$ http://www.franklingomes.adv.br/public/Concorr\%C3\%AAncia\%20Desleal\%20a\%20(des)neces sidade $\% 20 \mathrm{de} \% 20$ Exist $\%$ C3\%AAncia\%20de\%20Patente.pdf $>$. Acesso em 10 out. 2013.

${ }^{138}$ Art. $2^{\circ} \mathrm{A}$ proteção dos direitos relativos à propriedade industrial, considerado o seu interesse social e o desenvolvimento tecnológico e econômico do País, efetua-se mediante: $\mathrm{V}$ - repressão à concorrência desleal.

${ }^{139}$ PEREIRA, Marco Antonio Marcondes. Concorrência desleal por meio da publicidade. São Paulo: Juarez de Oliveira, 2001, p. 26.
} 
quanto aos outros dois tipos de publicidade que atentam contra a concorrência leal.

$\mathrm{O}$ art. 32 do CBAP, que dispõe sobre a publicidade comparativa, elencou os atos de denigração (alínea $\mathrm{f}$ ) e confusão (alíneas $e, g$ ) dentre as hipóteses de propaganda comparativa irregular. No entanto, na visão de Marco Antonio Marcondes Pereira, estes "constituem-se em modalidades próprias e autônomas de mensagens publicitárias ilícitas que ferem a concorrência" $" 140$.

Nas palavras de Rubens Requião, os atos denigradores "tendem deliberadamente a produzir o descrédito do competidor, ou de seus produtos mediante a difusão de notícias, juízos e informes falsos ou de insinuações tendenciosas e malévolas"141. A publicidade denigratória é enfrentada nos incisos I e II do art. 195 da Lei de Propriedade Industrial. Sobre estes, João da Gama Cerqueira explica que "as duas hipóteses mal se distinguem, pois em ambas se trata de falsa afirmação ou informação acerca do concorrente, suscetível de causar-lhe prejuízo, divulgada ou prestada com o fim de obter vantagem indevida ou com intuito de lucro"142.

A publicidade confusória é aquela que estimula a confusão, sendo esta, aquela que "advém da imitação ou uso indevido dos elementos identificadores de determinado empresário ou de seus sinais distintivos, por um concorrente." ${ }^{143}$ Para Carlos Alberto Bittar, "caracteriza-se a confusão, em uma análise global, por meio de práticas tendentes a captar, ilicitamente, clientela alheia, aproveitando-se alguém da imagem do concorrente"144. Além dos incisos V e VI do art. 195, o art. 189, $\mathrm{I}^{145}$, da Lei 9.279/96

\footnotetext{
${ }^{140}$ Ibid, p. 114.

${ }^{141}$ REQUIÃO, Rubens. Curso de Direito Comercial. 22a Ed. São Paulo: Saraiva, 1995, pp. 245246.

${ }^{142}$ CERQUEIRA, João da Gama. Tratado da propriedade industrial, v.2, t.2. Rio de Janeiro: Forense, 1956, p.3.

${ }^{143}$ PEREIRA, Marco Antonio Marcondes. Concorrência desleal por meio da publicidade. São Paulo: Juarez de Oliveira, 2001, p. 129.

${ }^{144}$ BITTAR, Carlos Alberto. Teoria e prática da concorrência desleal. São Paulo: Saraiva, 1989, p. 54.

145 Art. 189. Comete crime contra registro de marca quem:
} 
também dispõe sobre "comportamentos que causam confusão e são reprimidos penalmente" ${ }^{\text {}} 146$

De volta ao art. 195 da Lei 9.279/96, resta proceder à análise das demais hipóteses de publicidade que atentam contra a concorrência leal. Quanto ao inciso IV, o uso indevido de expressão ou sinal de propaganda alheios, ou a imitação que criar confusão entre produtos ou estabelecimentos, além de configurar crime de concorrência desleal, pode eventualmente caracterizar violação de direito autoral. É importante observar que - conforme será visto no próximo subcapítulo independentemente de registro, "os sinais e expressões de propaganda quando dotados de originalidade e criatividade encontram ampla proteção dentro do campo do direito autoral." ${ }^{\prime 47}$ Ainda quanto ao inciso IV, é valiosa a lição do Instituto Danneman Siemsen de Estudos de Propriedade Intelectual:

\begin{abstract}
Nesse inciso, temos duas formas de configuração do ilícito. A primeira é com a simples utilização, sem autorização, da expressão ou sinal de propaganda. Aqui, basta a verificação da vontade do agente, que deve ser livre e consciente, em utilizar indevidamente e sem qualquer autorização, expressão ou sinal de propaganda alheio, para a configuração do crime. Não há, portanto, a necessidade da conduta do agente repercutir perante os consumidores, de modo a confundilos. Aqui, portanto, a consumação do crime se verifica com a mera utilização indevida da expressão ou sinal de propaganda alheio, independentemente de qualquer repercussão.

Já na segunda hipótese, em que falamos de imitação, e não em utilização da própria expressão ou sinal, não basta que o agente tenha a vontade livre e consciente de concorrer deslealmente. É necessária a existência de possibilidade de confusão entre o sinal ou expressão que está utilizando, quando comparado com o violado" $" 148$.
\end{abstract}

O inciso VII do art. 195, por sua vez, tipifica como crime a publicidade que se apropria indevidamente de recompensa - "o prêmio ou

I - reproduz, sem autorização do titular, no todo ou em parte, marca registrada, ou imita-a de modo que possa induzir confusão;

\footnotetext{
${ }^{146}$ PEREIRA, Marco Antonio Marcondes. Concorrência desleal por meio da publicidade. São Paulo: Juarez de Oliveira, 2001, p. 133.

${ }^{147}$ Comentários á Lei da Propriedade Industrial, pag. 396. - IDS - Instituto Dannemann Siemsen de Estudos de Propriedade Intelectual - Rio de Janeiro: Renovar, 2005

${ }^{148}$ IDS - Instituto Dannemann Siemsen de Estudos de Propriedade Intelectual. Comentários á Lei da Propriedade Industrial. Rio de Janeiro: Renovar, 2005, p. 396.
} 
galardão que se dá a alguém ou alguma coisa"149 - ou distinção - "o ato que distingue, diferencia, entre seus pares ou similares"150. Este dispositivo apresenta forte preocupação de cunho consumerista:

Está intrinsecamente relacionada com a tutela das relações de consumo à medida que o consumidor também é afetado substancialmente (como na maioria dos casos de concorrência desleal) por ser atraído por " título" ostentado indevidamente, o que incrementa e potencializa significativamente o poderio do concorrente desleal, seja comercial ou industrial, em detrimento de seus concorrentes (aqui configurando a concorrência desleal) ${ }^{151}$.

\section{V.2. A proteção autoral das obras publicitárias}

$\mathrm{O}$ art. 7o da Lei 9.610/98, que regula os direitos autorais, determina que "são obras intelectuais protegidas as criações do espírito, expressas por qualquer meio ou fixadas em qualquer suporte, tangível ou intangível, conhecido ou que se invente no futuro." Nesta toada, de acordo com a lição de Carlos Alberto Bittar, a obra publicitária é uma “criação intelectual, de regra breve e expressiva, que se destina a promover a comunicação ao público de determinado produto ou serviço. Contém sempre uma mensagem, voltada para a sensibilização do público" ${ }^{152}$. Desta forma, segundo o mesmo autor, "as obras publicitárias recebem proteção autoral quanto às suas diferentes manifestações" ${ }^{\prime 153}$.

No entanto, para efetivamente gozar da proteção do direito autoral, é indispensável que a obra publicitária apresente os elementos de criatividade e originalidade. Estes são os requisitos intrínsecos à proteção de qualquer criação intelectual, como explica Elisângela Dias Menezes:

\footnotetext{
${ }^{149}$ DELMANTO, Celso. Crimes de Concorrência Desleal. São Paulo: Editora da Universidade de São Paulo, 1975, p. 153.

${ }^{150}$ Ibid, p. 153.

${ }^{151}$ IDS - Instituto Dannemann Siemsen de Estudos de Propriedade Intelectual. Comentários á Lei da Propriedade Industrial. Rio de Janeiro: Renovar, 2005, p. 396.

${ }^{152}$ BITTAR, Carlos Alberto. Direito de Autor na Obra Publicitária. São Paulo: Revista dos Tribunais, 1981, p. 117.

${ }^{153}$ BITTAR, Carlos Alberto. Direito do Autor, Rio de Janeiro: Forense Universitária, 2008, p. 83.
} 
As obras intelectuais precisam ser dotadas de elementos que a distingam de materiais ou produtos de uso meramente comum. Trata-se aqui de determinar a necessidade da criatividade, originalidade e da inventividade da mente do criador, como requisito de decisivos reflexos na conformação da obra, de modo que ela se torne diferente, nova, original e única ${ }^{154}$.

Desta forma, sempre que presentes os requisitos de criatividade e originalidade, a obra publicitária encontra-se protegida pela Lei 9.610/98. Nas palavras de Marco Antonio Marcondes Pereira, "a publicidade pode ser considerada uma obra intelectual protegida pela legislação de direito autoral, na medida em que estampe uma qualidade criativa do autor, que vai além da comunicação de um fato comum"155.

$\mathrm{Na}$ grande maioria das vezes, o resultado final da atividade de criação publicitária é classificado como uma obra coletiva, de acordo com a definição do art. $5^{\circ}$, VIII, h, da Lei 9.610/08 ${ }^{156}$. Do processo de elaboração de uma peça publicitária, podem participar diversos atores, como o redator publicitário, o diretor de arte, o arte-finalizador, o ilustrador, o fotógrafo, o produtor, o diretor de cena, entre outros. Desta forma, ainda que o resultado final seja uma obra coletiva, as criações publicitárias individuais também são protegidas em si mesmo. José de Oliveira Ascensão aborda o tema da seguinte forma:

Muito frequentemente também, a elaboração da mensagem publicitária origina uma obra coletiva. Isso acontece quando, nos termos gerais, a obra de conjunto pressupuser uma e empresa e não puder ser imputada a uma autoria singular. A complexidade da mensagem publicitária implica que muitas vezes as contribuições individuais se fundam numa obra de conjunto que não dominam, como elementos parcelares. A obra de conjunto é então da empresa. Os contributos individuais não deixam de ser por si obras. Sobre elas recaem direitos autônomos. Mas o exercício só a estes pode respeitar, e em termos que não prejudiquem a exploração da obra de conjunto ${ }^{157}$.

\footnotetext{
${ }^{154}$ MENEZES, Elisângela Dias. Curso de Direito Autoral. Belo Horizonte: Ed. Del Rey, 2007, p. 16.

${ }^{155}$ PEREIRA, Marco Antonio Marcondes. Concorrência desleal por meio da publicidade. São Paulo: Juarez de Oliveira, 2001, p. 37.

${ }^{156}$ Art. $5^{\circ}$ Para os efeitos desta Lei, considera-se: VIII - obra: h) coletiva - a criada por iniciativa, organização e responsabilidade de uma pessoa física ou jurídica, que a publica sob seu nome ou marca e que é constituída pela participação de diferentes autores, cujas contribuições se fundem numa criação autônoma.
}

${ }^{157}$ ASCENSÃO, José de Oliveira. Direito Autoral. Rio de Janeiro: Renovar, 1997, p. 453. 


\section{Carlos Alberto Bittar também apresenta valiosa lição:}

A regra é a da existência da obra coletiva, porque de iniciativa da agência, que mantém sob emprego os vários elaboradores nela utilizados, configurando a obra final (texto, jingle, filme etc) conjunto incindível, no qual não de pode individualizar a contribuição de cada um. (...) Também quando, no contexto de uma obra coletiva, houver criação estética autônoma individualizada - por exemplo, em um anúncio feito em tela, a pintura idealizada ou executada por um só artista; em um jingle, a composição musical criada por um só Autor prevalecerá a orientação referida quanto a essa obra em si, destacável do conjunto, sem prejuízo do direito sobre o conjunto ${ }^{158}$.

Nos termos do $\S 2^{\circ}$ do art. 17 da Lei 9.610/98 ${ }^{159}$, caberá à agência de publicidade, considerando que esta é a responsável por organizar todos as etapas da criação conjunta e pelo resultado final do trabalho, a titularidade dos direitos patrimoniais da obra coletiva. Já os direitos autorais morais ficam "resguardados aos criadores, pessoas físicas, face ao seu caráter personalíssimo." ${ }^{~} 160$ Carlos Alberto Bittar assim dispõe sobre a matéria:

São, pois, titulares de direitos na publicidade: a) os criadores, os que elaboram obra individualizada ou individualizável (nesse rol se incluem os escritores, poetas, compositores, atores, intérpretes e outros); b) a agência,

na hipótese de obra coletiva (ou seja, elaborada através da conjugação da contribuição de diversos criadores, mas sob a direção da agência, de modo que não se possa, na obra final, individualizar a colaboração de cada qual);

c) a produtora, nas mesmas condições da agência (seja de fonograma, seja de filme). Assinale-se, outrossim, que, em qualquer caso, à agência (ou à produtora) cabem os direitos sobre a obra final nela produzida (o anúncio em seu conjunto, o fonograma como tal, o filme, e assim por diante), que coexistem com os direitos dos autores de obra individualizada ou individualizável que a integre (exemplo: o autor do texto, do desenho, da música) ${ }^{161}$.

Por fim, como Mariana Galvão constata de maneira pertinente, é curioso "observar que, ao Cliente Anunciante não cabe qualquer titularidade sobre a obra publicitária, salvo se os direitos patrimoniais forem

\footnotetext{
${ }^{158}$ BITTAR, Carlos Alberto. O Direito de Autor nos Meios Modernos de Comunicação. São Paulo: Revista dos Tribunais, 1989.

${ }^{159}$ Art. 17. É assegurada a proteção às participações individuais em obras coletivas.

$\S 2^{\circ}$ Cabe ao organizador a titularidade dos direitos patrimoniais sobre o conjunto da obra coletiva.

${ }^{160}$ GALVÃO, Mariana L. Criação publicitária e a lei autoral. Disponível em

$<$ http://www2.uol.com.br/direitoautoral/artigo0904.htm>. Acesso em 01 out. 2013.

${ }^{161}$ BITTAR, Carlos Alberto. Contornos atuais do direito do autor. São Paulo: Revista dos

Tribunais, 1999, $2^{\mathrm{a}}$ edição, revista, atualizada e ampliada.
} 
cedidos pelos titulares originais através de contrato de cessão de direitos" $" 162$.

162 GALVÃO, Mariana L. Criação publicitária e a lei autoral. Disponível em $<$ http://www2.uol.com.br/direitoautoral/artigo0904.htm>. Acesso em 01 out. 2013. 


\section{A autorregulamentação publicitária em outros países}

\section{VI.1. Reino Unido}

O regime britânico de regulação da publicidade é uma combinação única de case law, direito positivado e autorregulação ${ }^{163}$. Monlee Lee e Carla Johnson explicam que esse modelo difere dos sistemas regulatórios existentes nos Estados Unidos e nos países da Europa continental em dois aspectos principais: (i) ausência de leis escritas que proíbam propaganda enganosa e desleal; (ii) papel de destaque desempenhado pelo órgão autorregulador no controle de abusos específicos ${ }^{164}$.

O sistema britânico talvez seja o modelo mais bem acabado de autorregulação publicitária no mundo, tendo servido como principal referência para a criação do brasileiro. Mantido por uma taxa de $0.1 \%$ cobrada sobre o preço de venda dos espaços de mídia publicitária ${ }^{165}$, a Advertising Standards Authority (ASA) é o maior, mais ativa, e mais rica autoridade de autorregulação da propaganda no mundo. A absoluta maioria das reclamações referentes ao conteúdo de anúncios publicitários é direcionada, em primeira instância à ASA. Como Monlee Lee e Carla Johson explicam, a interferência do Estado nesses casos é a exceção e ocorre apenas quando a violação ultrapassa a esfera de atuação da autorregulação $^{166}$.

O CAP, criado em 1961, é o órgão responsável pela redação e atualização da versão britânica do nosso Código de Autorregulamentação Publicitária: o British Code and Advertising, Sales Promotion and Direct Marketing. Os princípios básicos que norteiam esse documento são os de

\footnotetext{
${ }^{163}$ LEE, Monlee; JOHNSON, Carla. Principles of Advertising: A Global Perspective. New York: The Haworth Press, 2005, p. 62.

${ }^{164}$ Ibid, p. 62

${ }^{165}$ Self-Regulation in the EU Advertising Sector: A report of some discussion among interested parties, p. 33. Disponível em $<\mathrm{http} / / / \mathrm{www}$.asa.co.nz/pdfs/Madelin\%20Report.pdf $>$. Acesso em 02 set. 2013.

${ }^{166}$ LEE, Monlee; JOHNSON, Carla. Principles of Advertising: A Global Perspective. New York: The Haworth Press, 2005, p. 63.
} 
que a publicidade deverá ser: (i) legal, decente, honesta e verdadeira; (ii) elaborada com um senso de responsabilidade para com os consumidores e a sociedade; (iii) condizente com os princípios da concorrência leal ${ }^{167}$. Barbara Mueller explica que, no Reino Unido, as consequências para os anunciantes que não observarem as regras da autorregulação podem ser muito severas. Em casos extremos, o anunciante pode até ser proibido de veicular anúncios em qualquer mídia durante certo período de tempo ${ }^{168}$.

Ao contrário do CONAR, a ASA tem a prerrogativa de vetar previamente a veiculação de propagandas. Vinte e cinco categorias de anúncios estão sujeitas a este controle a priori, como propagandas religiosas, de bebidas alcóolicas, relacionadas à saúde, e aquelas narradas por crianças ${ }^{169}$. A grande maioria dos anúncios de televisão e spots de rádio no Reino Unido, por sinal, passam por uma "triagem" pela ASA antes de ser veiculados ${ }^{170}$.

Assim como ocorre na autorregulação brasileira, uma reclamação de um único consumidor já é suficiente para que a ASA dê início ao processo de julgamento de um anúncio ${ }^{171}$. É importante observar que a ASA foi uma das pioneiras na implementação de restrições às propagandas de cigarro no mundo, tendo proibido, desde 1994, o uso de humor nos anúncios e a colocação de outdoors de empresas de cigarro a menos de duzentos metros de escolas ${ }^{172}$.

\section{VI.2. Estados Unidos}

\footnotetext{
${ }^{167}$ MUELLER, Barbara. Dynamics of International Advertising: Theoretical and Practical Perspectives. New York: Peter Lang Publishing, Inc., 2011, p. 312.

${ }^{168}$ Ibid, p. 312.

${ }^{169}$ SHAH, Kruti; D'SOUZA, Alan. Advertising \& Promotions: an IMC perspective. New Dheli: Tata McGraw-Hill, 2009, p. 918.

${ }_{170}$ About regulation. Disponível em $<\mathrm{http}$ //www.asa.org.uk/About-ASA/About-regulation.aspx $>$. Acesso em 03 set. 2013.

${ }^{171}$ About regulation. Disponível em $<$ http://www.asa.org.uk/About-ASA/About-regulation.aspx $>$. Acesso em 03 set. 2013.

${ }^{172}$ LEE, Monlee; JOHNSON, Carla. Principles of Advertising: A Global Perspective. New York: The Haworth Press, 2005, p. 63.
} 
O principal órgão responsável pela autorregulação da publicidade nos Estados Unidos é a National Advertising Division (NAD). No entanto, cabe ao Advertising Self-Regulatory Council (ASRC) estabelecer as políticas gerais e os procedimentos para a autorregulação da indústria ${ }^{173}$. E a NDA, por sua vez, é administrada pelo Council of Better Business Bureaus (CBBB). Além destes órgãos, o sistema de autorrregulação publicitária ainda engloba a Children's Advertising Review Unit (CARU), responsável pela autorregulação da publicidade infantil, e o Electronic Retailing Self-Regulation Program (ERSP), encarregado de autorregular a publicidade de anunciantes de varejo eletrônico ${ }^{174}$.

Criada em 1971, a NAD surgiu com o intuito de promover a verdade e a exatidão na publicidade norte-americana ${ }^{175}$. O órgão recebe reclamações de consumidores, anunciantes e agências, e também pode iniciar investigações de ofício, através da monitoração contínua que exerce sobre a indústria ${ }^{176}$. A NAD ocupa-se apenas de anúncios veiculados nacionalmente ou com grande exposição regional ${ }^{177}$. Tratando-se de anúncio divulgado somente em nível local, a análise quanto às possíveis infrações éticas cabe à sessão do CBBB mais próxima do anunciante ${ }^{178}$.

A NAD julga em média cem casos por ano, e o processo todo - da queixa até a decisão - demora aproximadamente sessenta dias. Todos os membros da NAD, responsáveis pelo julgamento e decisão dos casos, são advogados especializados no assunto ${ }^{179}$. Chama atenção o fato de que, ainda que a adesão ao órgão seja voluntária, se algum anunciante

\footnotetext{
${ }^{173}$ ASRC Snapshot. Disponível em <http://www.asrcreviews.org/>. Acesso em 14 out. 2013

${ }^{174}$ ASRC Snapshot. Disponível em <http://www.asrcreviews.org/>. Acesso em 14 out. 2013

${ }^{175}$ VILLAFRANCO, John E.; RILEY, Katherine E. So You Want to Self-Regulate? The National Advertising Division As Standard Bearer. In: Antitrust, Vol. 27, No. 2, Spring 2013, p. 79.

Disponível em <http://www.kelleydrye.com/publications/articles/1703/_res/id=Files/index=0/>. Acesso em 15 out. 2013.

${ }^{176}$ VILLAFRANCO, John E.; RILEY, Katherine E. So You Want to Self-Regulate? The National Advertising Division As Standard Bearer. In: Antitrust, Vol. 27, No. 2, Spring 2013, p. 79.

Disponível em $<$ http://www.kelleydrye.com/publications/articles/1703/_res/id=Files/index=0/>. Acesso em 15 out. 2013.

177 About NAD. Disponível em <http://www.bbb.org/us/About-NAD/>. Acesso em 15 out. 2013.

${ }^{178}$ About NAD. Disponível em <http://www.bbb.org/us/About-NAD/>. Acesso em 15 out. 2013.

${ }^{179}$ About NAD. Disponível em <http://www.bbb.org/us/About-NAD/>. Acesso em 15 out. 2013.
} 
denunciado se recusar a participar do processo, ou não cumprir a decisão final, a NAD pode encaminhar o caso para o órgão regulador competente em geral, o FTC. ${ }^{180}$ De qualquer forma, cerca de $95 \%$ das agências de publicidade norte-americanas são filiadas à $\mathrm{NAD}^{181}$, e o cumprimento das suas decisões pelos anunciantes e agências é quase absoluto. Entre 1971 e 1985, todas as decisões tomadas pelo órgão foram respeitadas, e no período entre 1985 e 2000 , por exemplo este índice ficou em $96 \%{ }^{182}$.

\footnotetext{
${ }^{180}$ VILLAFRANCO, John E.; RILEY, Katherine E. So You Want to Self-Regulate? The National Advertising Division As Standard Bearer. In: Antitrust, Vol. 27, No. 2, Spring 2013, p. 79.

Disponível em $<$ http://www.kelleydrye.com/publications/articles/1703/_res/id=Files/index=0/>. Acesso em 15 out. 2013.

${ }^{181}$ MEDINA, Mercedes; AN, Soontae. Advertising self-regulation activity: A Comparison between Spain and US. p. 22. Disponível em $<$ http://www.ehu.es/zer/hemeroteca/pdfs/zer33-01medina.pdf $>$. Acesso em 15 out. 2013.

${ }^{182}$ LATIMER, Hugh; HALE, Christopher. NAD Procedures for Resolving Advertising Disputes: Simple, Swift and Effective, Vol. 9, No. 7 (July 2001). Disponível em $<$ http://www.wileyrein.com/docs/publications/11488.pdf.>. Acesso em 16 out. 2013.
} 


\section{Conclusão}

A publicidade pode assumir diversas formas, pode ser criativa ou ser mais do mesmo, fazer chorar ou fazer rir. O que a propaganda não pode é passar por cima, e muito menos ao lado, da ética. E, se uma das definições de "ética" é o "conjunto de princípios morais que se devem observar no exercício de uma profissão" ${ }^{\text {"183 }}$, não existe defensor maior da ética na atividade publicitária do que o CONAR.

A autorregulação exercida pelo CONAR, fundamentada nas regras e princípios do Código Brasileiro de Autorregulamentação Publicitária, também representa importantíssimo mecanismo para a defesa da concorrência na atividade econômica. E também dos direitos e interesses dos consumidores, na medida em que representa um canal gratuito e eficiente para os consumidores que se sentirem de alguma forma lesados por determinada propaganda.

Ainda que se possa argumentar que sistemas autorregulatórios não possuem força coercitiva para fazerem valer as suas decisões, no caso do mercado publicitário, a eficácia e o poder vinculativo das deliberações do órgão autorregulador, na prática, é impressionante e faz cair por terra esses argumentos. Inclusive, J.J. Boddewyn, professor da New York University e um dos maiores especialistas do mundo em regulação publicitária, sustenta que "o modelo do Brasil é provavelmente o mais desenvolvido sistema de auto-regulamentação encontrado em países em desenvolvimento e até sobrepuja alguns do primeiro mundo" ${ }^{\prime 184}$.

Ante tudo o que foi exposto, conclui-se que, guiado pelas normas e princípios do Código Brasileiro de Autorregulamentação Publicitária, o CONAR - e o sistema de autorregulação da publicidade como um todo -, desde a sua criação nos tempos sombrios da ditadura, tem se mostrado um

\footnotetext{
${ }^{183}$ Michaelis - Dicionário de Português Online. Disponível em $<$ http://michaelis.uol.com.br/moderno/portugues/index.php?lingua=portuguesportugues\&palavra $=\%$ E9tica $>$. Acesso em 15 out. 2013.

${ }^{184}$ SCHNEIDER, ARI. CONAR 25 anos: ética na prática. São Paulo: Terceiro Nome, 2005, p. 22.
} 
intransigente defensor da ética e moralidade na atividade publicitária, da concorrência leal e dos direitos do consumidor. E assim espera-se que continue sendo. 


\section{BIBLIOGRAFIA:}

ARRUDA, Maria Cecilia Coutinho de. A Ética na Propaganda. Escola de Administração de Empresas de São Paulo, Fundação Getúlio Vargas, NPP, Núcleo de Pesquisas e Publicações, 1995

ASCENSÃO, José de Oliveira. Direito Autoral. Rio de Janeiro: Renovar, 1997.

AZEVEDO, Reinaldo. Cristo e o Red Bull. Ou: Maomé jamais apareceria tomando um energético. 30 mar. 2012. Blog Reinaldo Azevedo - Veja. Disponível em <http://veja.abril.com.br/blog/reinaldo/geral/cristo-e-o-redbull-ou-maome-jamais-apareceria-tomando-um-energetico/>.

BENJAMIN, Antônio Herman de Vasconcellos e. In.: Ada Pellegrini Grinover [et al.] In Código Brasileiro de Defesa do Consumidor: comentado pelos autores do anteprojeto. Rio de Janeiro: Forense, 2001.

BENJAMIN, Antônio Herman V.; MARQUES, Claudia Lima; BESSA, Leonardo Roscoe. Manual de Direito do Consumidor. 3. ed. rev., atual. eampl. São Paulo: Editora Revista dos Tribunais, 2010.

BENJAMIN, Antônio Herman de Vasconcellos e. O controle jurídico da publicidade. Revista de Direito do Consumidor, São Paulo, n. 9, jan/mar. 1994.

BITTAR, Carlos Alberto. Contornos atuais do direito do autor. São Paulo: Revista dos Tribunais, 1999, $2^{\text {a }}$ edição, revista, atualizada e ampliada. 
BITTAR, Carlos Alberto. Direito do Autor, Rio de Janeiro: Forense Universitária, 2008.

BITTAR, Carlos Alberto. Direito de Autor na Obra Publicitária. São Paulo: Revista dos Tribunais, 1981.

BITTAR, Carlos Alberto. O Direito de Autor nos Meios Modernos de Comunicação. São Paulo: Revista dos Tribunais, 1989.

BRITO, Judith. O consumidor não precisa de tutela. Disponível em:

$<$ www.conar.org.br $>$.

CARISTINA, José Eduardo Aguiar. Os modelos jurídicos na autoregulação econômica. Prisma Jurídico, São Paulo, v.5, 2006.

CASTRO, Daniel. Benefits and Limitations of Industry Self-Regulation for Online Behavioral Advertising. Disponível em $<$ http://www.ntia.doc.gov/files/ntia/2011-self-regulation-online-behavioraladvertising.pdf $>$.

CERQUEIRA, João da Gama. Tratado da propriedade industrial, v.2, t.2. Rio de Janeiro: Forense, 1956.

COELHO, Fábio Ulhoa. Curso de Direito Comercial. São Paulo: Saraiva, 1998.

COELHO, Fábio Ulhoa, $O$ empresário e os direitos do consumidor. São Paulo: Saraiva, 1994.

COSTA, Antonio Carlos Gomes da. Natureza e implantação do novo direito da criança e do adolescente. In: PEREIRA, Tânia da Silva (Coord.). 
Estatuto da Criança e do Adolescente: Lei 8.069/90: estudos sóciojurídicos. Rio de Janeiro: Renovar, 1992.

DELMANTO, Celso. Crimes de Concorrência Desleal. São Paulo: Editora da Universidade de São Paulo, 1975.

DURIGAN, Paulo Luiz. Publicidade comparativa: informação persuasiva e concorrência. Curitiba, 2007, 268 f. Dissertação (Mestrado em Direito). Faculdades Integradas Curitiba. Disponível em $<$ http://www.apriori.com.br/artigos/publicidadecomparativa.pdf $>$.

DUVAL, Hermano. Concorrência desleal. São Paulo: Saraiva, 1976.

GALVÃO, Mariana L. Criação publicitária e a lei autoral. Disponível em $<$ http://www2.uol.com.br/direitoautoral/artigo0904.htm>.

GARCIA, Leonardo de Medeiros. Direito do Consumidor: Código Comentado e Jurisprudência. Niterói: Impetus, 2010.

GOMES, Franklin. A (Des)necessidade de existência de patente. Disponível em $<$ http://www.franklingomes.adv.br/public/Concorr\%C3\%AAncia\%20Desle al $\% 20 \mathrm{a} \% 20$ (des)necessidade $\% 20 \mathrm{de} \% 20$ Exist $\%$ C3\%AAncia $\% 20 \mathrm{de} \% 20$ Pat ente.pdf $>$.

GUNNINGHAM, Neil; REES, Joseph. Industry Self-Regulation: An Institutional Perspective. Disponível em $<$ http://onlinelibrary.wiley.com/store/10.1111/1467-9930.t01-100033/asset/1467-9930.t01-100033.pdf? $\mathrm{v}=1 \& \mathrm{t}=\mathrm{hn} 9 \mathrm{knji} 8 \& \mathrm{~s}=\mathrm{ad} 907 \mathrm{~b} 6621148 \mathrm{a} 8$ fae $78 \mathrm{~b} 4 \mathrm{a} 4 \mathrm{a} 871615 \mathrm{fc} 58 \mathrm{~b}$ $5714>$. 
GUPTA, Anil K.; LAD, Lawrence J. Industry Self-Regulation: An Economic, Organizational, and Political Analysis. Boston: The Academy of Management Review 8 no. 3, 1983.

HENRIQUES, Isabela Vieira Machado. Publicidade abusiva dirigida à criança. Curitiba, Editora Jaruá, 2006.

IDS - Instituto Dannemann Siemsen de Estudos de Propriedade Intelectual. Comentários á Lei da Propriedade Industrial. Rio de Janeiro: Renovar, 2005.

JACOBINA, Paulo Vasconcelos. A publicidade no direito do consumidor. Rio de Janeiro: Forense, 2002.

LATIMER, Hugh; HALE, Christopher. NAD Procedures for Resolving Advertising Disputes: Simple, Swift and Effective, Vol. 9, No. 7 (July 2001). Disponível em $<$ http://www.wileyrein.com/docs/publications/11488.pdf.>.

LEE, Monlee; JOHNSON, Carla. Principles of Advertising: A Global Perspective. New York: The Haworth Press, 2005.

MAGAlHãeS DiAS, Lucia Ancona Lopez de. Publicidade e Direito. São Paulo: RT, 2010.

MEDINA, Mercedes; AN, Soontae. Advertising self-regulation activity: A Comparison between Spain and US. p. 22. Disponível em $<$ http://www.ehu.es/zer/hemeroteca/pdfs/zer33-01-medina.pdf $>$. Acesso em 15 out. 2013. 
MENEZES, Elisângela Dias. Curso de Direito Autoral. Belo Horizonte: Ed.

Del Rey, 2007.

MUELLER, Barbara. Dynamics of International Advertising: Theoretical and Practical Perspectives. New York: Peter Lang Publishing, Inc., 2011.

PASQUALOTO, Adalberto. Os efeitos Obrigacionais da Publicidade no Código de Defesa do Consumidor. São Paulo: RT, 1997.

PEREIRA, Marco Antonio Marcondes. Concorrência desleal por meio da publicidade. São Paulo: Juarez de Oliveira, 2001.

PERES, Lucas da Silva. O tratamento autorregulamentar da publicidade abusiva que fere o "princípio geral da decência. Ribeirão Preto. 2012. p. 79. Monografia - Universidade de São Paulo - Faculdade de Direito de Ribeirão Preto.

REQUIÃO, Rubens. Curso de Direito Comercial. 22a ed. São Paulo: Saraiva, 1995.

SAMPAIO, Rafael. Propaganda de A a Z. Rio de Janeiro: Elsevier, 2003.

SANT’ANNA, Armando. Propaganda: Teoria, Técnica e Prática, 3 a ed. São Paulo, Pioneira, 1982.

SANTOS, Fernando Gherardini. Direito do Marketing: uma abordagem jurídica do marketing empresarial. São Paulo: Ed. Revista dos Tribunais, 2000

SCHNEIDER, ARI. CONAR 25 anos: ética na prática. São Paulo: Terceiro Nome, 2005. 
SHAH, Kruti; D'SOUZA, Alan. Advertising \& Promotions: an IMC perspective. New Dheli: Tata McGraw-Hill, 2009.

VILLAFRANCO, John E.; RILEY, Katherine E. So You Want to SelfRegulate? The National Advertising Division As Standard Bearer. In: Antitrust, Vol. 27, No. 2, Spring 2013, p. 79. Disponível em $<$ http://www.kelleydrye.com/publications/articles/1703/_res/id=Files/index $=0 />$. 